\title{
REMIGIUS AND THE 'IMPORTANT NEWS’ OF CLOVIS REWRITTEN
}

\author{
GRAHAM BARRETT AND GEORGE WOUDHUYSEN
}

\section{Remi et la 'nouvelle importante' de Clovis réécrits}

Cet article est un nouvel examen de la Lettre austrasienne $n^{\circ} 2$, adressée par Remi, évêque de Reims, à Clovis, roi des Francs. Nous proposons une nouvelle transcription du texte, accompagnée d'une traduction, et suivie d'une étude des interprétations proposées du Moyen Âge à nos jours, ainsi que d'un commentaire linéaire. La conclusion propose une révision radicale de la date et de la signification de la lettre. Nous démontrons que cette dernière ne doit pas être datée nécessairement du début du règne de Clovis, ni à la suite d'une campagne spécifique, et qu'elle ne peut être interprété comme une preuve ni de la prise de contrôle par Clovis de l'administration de la province romaine de Belgique seconde, ni du fait qu'il aurait reçu de l'empereur une charge officielle. Nous affirmons que la lettre doit être datée de la fin du règne de Clovis, et qu'elle doit être lue comme une preuve de continuité dans le styleplutôt que dans la substance - du gouvernement du monde romain. [Auteurs]

The lyric glorification of a misunderstood text does not commend itself to a sober mind; and it often happens that those who sneer at the deadness of the mere grammarian mistake disdain of the interpreter of the beautiful for indifference to the beautiful itself.

Basil Gildersleeve ${ }^{1}$

* We should like to express our gratitude here to Thomas Charles-Edwards, Franz Dolveck, David Ganz, Justin Stover, Chris Wickham, Hannah Williams, Ian Wood; and, still, to Emily Troscianko.

** We employ the following abbreviations throughout:

BAV Biblioteca Apostolica Vaticana

BECh Bibliothèque de l'École des Chartes

$\mathrm{BnF} \quad$ Bibliothèque nationale de France

DI Divinae Institutiones

DLH Decem Libri Historiarum

EME Early Medieval Europe

EA Epistulae Austrasicae

Ep Epistula

MIÖG Mitteilungen des Österreichischen Instituts für Geschichtsforschung

ML Mémoires de littérature tiréz des registres de l'Académie Royale des Inscriptions et Belles-Lettres

NA Neues Archiv der Gesellschaft für ältere deutsche Geschichtskunde

OCV Les cuvres complètes de Voltaire

OLD P.G.W. Glare (ed.), Oxford Latin Dictionary, $2^{\text {nd }}$ ed., 2 vols., Oxford, 2012

Pan Lat R.A.B. Mynors (ed.), XII Panegyrici Latini, Oxford, 1964

RBPH Revue Belge de Philologie et d'Histoire

SSRM Scriptores Rerum Merowingicarum

TLL Thesaurus Linguae Latinae, Leipzig, 1900-

*** Where not stated we have consulted the edition of reference used by the Cross-Database Searchtool (online at http://clt.brepolis.net/cds/Default.aspx).

1 Quoted in Gildersleeve's Latin Grammar, Wauconda, 1997, p. xi. 


\section{Introduction}

What is to be done with Epistula Austrasica 2? This letter, from Remigius, bishop of Reims and apostle of the Franks, to Clovis (481-511), founder of the Merovingian kingdom, is that rarest of items: a contemporary source for his reign. The potential significance of it cannot be overstated, and in outline its contents are straightforward. Remigius has heard important news' of Clovis, which prompts the bishop to compare the king to his ancestors, and then to give him advice, mostly conventional, on how to rule. The letter promises to answer some of the most debated questions of that age. What position did Clovis occupy, and what was the nature of his authority? Did his ancestors exercise the same? When did Clovis become a Christian, and with what consequences? Yet on closer inspection, the meaning of the letter is difficult to retrieve: at points it is not clear what the text is or should be, and even absent such problems the precise import of the words remains elusive. Every reader has grappled with these challenges, some more successfully than others, but the present state of interpretation, when probed, is confused and contradictory: editions have circumvented the textual problems by emendation, and commentaries the historical ones by omission. These two approaches have enabled three interlinked positions to prevail: that the letter congratulates Clovis specifically on assuming the government of the former Roman province of Belgica Secunda; that it dates to early in his reign, no later than 486; and that he was then still pagan. None of them is secure. In their place, clarity and honesty are needed: clarity as to how the text has been and may be understood, honesty as to the provisional nature of any interpretation ventured. We offer a new transcription and translation of the letter, reviewing its reception to determine how its threefold signification has been determined. We then provide an interpretive commentary yielding a new critical text justified by our analysis, and conclude with what the letter, firmly grounded, can be made to mean. The results may surprise. 


\section{Transcription}

We present the letter as it now exists, a composite. The primary scribe of the manuscript, represented by the sign $c^{i}$, copied it in the early $9^{\text {th }}$ century. From that time onward, $c^{i i}$, a composite label for a number of correctors, revised it, adding punctuation; many annotations are too exiguous for secure identification of hand or date, but most are contemporary with or slightly later than the copying itself, and the balance belong to the $11^{\text {th }}$ century. Finally, $c^{i i i}$, a reader in the $14^{\text {th }}$ century, annotated the letter. ${ }^{2}$ Most editions claim to privilege the 'raw text' of $c^{i}$, yet also make emendations and additions in deference to $c^{i i}$, creating palimpsests which reflect no single source or consistent critical rationale. In contrast, we aim to present the extant data as clearly as possible, recognizing the need to simplify in the case of the corrector(s) by using a single sign and including all punctuation without assigning responsibility. In practice, as it now exists means transcribing the text as corrected by $c^{i i}$, while noting the base text of $c^{i}$. When a text survives in a unique and problematic manuscript diplomatic transcription is the safest approach: presenting all the layers together takes advantage of all the information which is available to us. ${ }^{3}$ The reader can thereby perceive the various strata of this single source for our letter insofar as they can be perceived.

Vatican, BAV, Pal. lat. 869 , fol. 3v. ${ }^{4}$

$c^{i} \quad$ Copyist (early $9^{\text {th }}$ century)

2 W. Gundlach, Epistolae Austrasicae, in E. Dümmler (dir.), Epistolae Merowingici et Karolini Aevi I. MGH Epistolae III, Berlin, 1892, pp. 110, 113, identified two correctors, $a$ ( $9^{\text {th }}$ century) and $b$ (1 $1^{\text {th }}$ century). While he declared that $a$ intervened in letters 1-4, his apparatus identifies only corrections by $b$ in the text of $E A 2$; E. Malaspina, Il Liber epistolarum della cancelleria austrasica (sec. V-VI), Rome, 2001, pp. 34-7, counters that most corrections look like the work of the earlier hand.

3 M.L. West, Textual Criticism and Editorial Technique Applicable to Greek and Latin Texts, Stuttgart, 1973, pp. 94-5; R. Tarrant, Texts, Editors, Readers: Methods and Problems in Latin Textual Criticism, Cambridge, 2016, p. 143.

4 For the excellent online digital facsimile with which we have worked, see http://bibliotheca-laureshamensisdigital.de/bav/bav_pal_lat_869/0012. 
$c^{i i} \quad$ Corrector(s) (early $9^{\text {th }}-11^{\text {th }}$ centuries)

$c^{\text {iii }} \quad$ Commentator $\left(14^{\text {th }}\right.$ century $)$

F M. Freher, Epistolae Francicae, in Corpus Francicae Historiae Veteris et Sincerae, Hanover, 1613 , no. 2 , p. $184 .^{5}$

S J. Sirmond, Remigii Episcopi Remorum Epistola II, in Concilia Antiqua Galliae, 3 vols., Paris, 1629,1, p. $175 .^{6}$

$G^{i} \quad$ W. Gundlach, Epistolae Austrasicae, in E. Dümmler (dir.), Epistolae Merowingici et Karolini Aevi I. MGH Epistolae III, Berlin, 1892, no. 2, p. $113 .^{7}$

$G^{i i} \quad$ W. Gundlach, F. Rommel (rev.), Epistulae Austrasicae, in H.M. Rochais (dir.), Defensoris Locogiacensis Monachi Liber Scintillarum. CCSL 117, Turnhout, 1957, no. 2, pp. 408-9.

$M^{i} \quad$ E. Malaspina, Il Liber epistolarum della cancelleria austrasica (sec. V-VI), Rome, 2001, no. 2, pp. 62-5.

$M^{i i} \quad$ R.W. Mathisen, People, Personal Expression, and Social Relations in Late Antiquity, 2 vols., Ann Arbor, 2003, 2, no. 4.13, pp. 108-9.

1 II ${ }^{8}$ DOMINO INSIGNI ET MERITIS MAGNIFICO hlodoûeo 9

$2 \quad \dot{R} E G I$ REMIGIUS ${ }^{10}$ EPISCOPUS

$5 \quad$ Repr. in A. du Chesne (ed.), Historiae Francorum Scriptores Coaetanei, 5 vols., Paris, 1636-49, 1, p. 849; T. Ruinart (ed.), S. Georgii Florentii Gregorii Turonensis Episcopi Opera Omnia, Paris, 1699, cols. 1326-7; M. Bouquet (ed.), Recueil des Historiens des Gaules et de la France, 24 vols., Paris, 1738-1904, 4, pp. 51-2.

6 Repr. in P. Labbé, G. Cossart (ed.), Sacrosancta Concilia ad Regiam Editionem Exacta, 17 vols., Paris, 16712, 4, cols. 1401-2; G.D. Mansi (ed.), Sacrorum Conciliorum Nova et Amplissima Collectio, 31 vols., Florence, 1759-93, 8, cols. 345-6; J. Gesquier et al. (ed.), AA.SS. Octobris I, Antwerp, 1765, pp. 91-2; Conciliorum Galliae, tam Editorum quam Ineditorum, Collectio, Paris, 1789, cols. 827-8; J.-P. Migne (ed.), PL, 221 vols., Paris, 1844-64, 65, cols. 965-8.

7 Repr. in C. Silva-Tarouca (ed.), Fontes Historiae Ecclesiasticae Medii Aevi, Rome, 1930, pp. $43-4$.

8 om. $S G^{i} G^{i i} M^{i} M^{i i}$. Utinam sic hodie esset mens regibus et sacerdotibus ] add. $c^{i i i}$ (superscript).

9 Chlodoveo $F S$.

10 REMEGIUS $c^{i} G^{i} G^{i i} M^{i}$. 
3 Rumor ad nos magnum ${ }^{11}$ peruenit $\cdot$ administrationem uos se-

$4 \quad \dot{\mathrm{r}}^{12}$ cundum ${ }^{13}$ bellice ${ }^{14}$ suscepisse ; non est nouum $\cdot$ ut coeperis esse sicut

5 parentes tui semper fuerunt $\cdot$ Hoc inprimis ${ }^{15}$ agendum $\cdot$ ut domini

6 iudicium a te $/ /$ non ${ }^{16}$ uacillet $^{17} \cdot \mathrm{ubi}^{18}$ tui meriti qui per industriam

7 humilitatis tuae ad summum culminisque ${ }^{19}$ peruenit $\cdot$ quia

8 quod $\cdot$ uulgus ${ }^{20}$ dicitur $\cdot$ actus $^{21}$ hominis probatur ; consiliarios

9 tibi adhibere debes qui famam // tuam possint ${ }^{22}$ ornare $\cdot$ et bene-

$10\left\{{ }^{23}\right.$ ficium tuum castum et honestum esse debet .' et sacerdotibus

11 t tuis honore ${ }^{24}$ debebis deferre .' et ad eorum consilia semper // recurrere $^{25}$;

$12\left\{\right.$ quod $\mathrm{si}^{26}$ tibi bene cum illis conuenerit · prouincia tua melius

13 \{ potest constare ; ciues ${ }^{27}$ tuos erige .' adflictos ${ }^{28}$ releua .' uiduas

$14 \dot{\mathrm{r}}^{29}$ foue .' orfanos ${ }^{30}$ nutri $^{31}$.' si potius est qu.am èrudies ${ }^{32}$ ut omnes te-

15 ament et timeant - Iustitia ex ore uestro procedat ; nihil sit

16 sperandum de pauperibus ${ }^{33}$ uel peregrinis .' ne magis dona aut

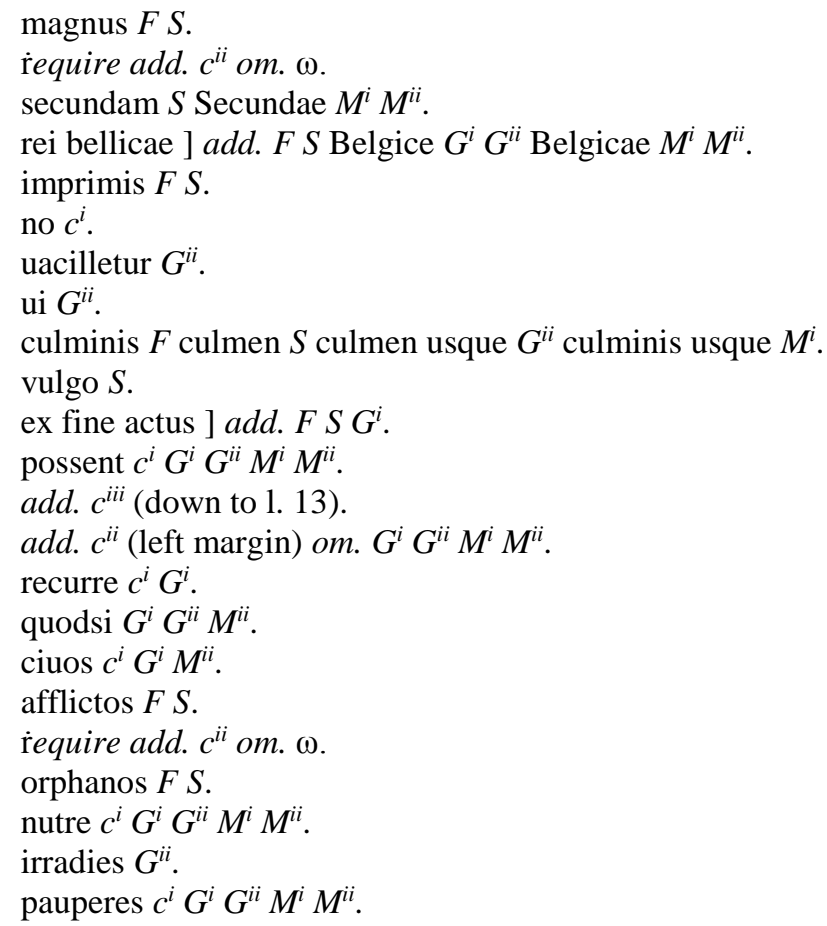


17 aliquid accipere uelis ${ }^{34}$; praetorium tuum omnibus pateatur ${ }^{35}$.

18 ut nullus exinde tristis abscedat; paternas quascumque $e^{36}$ opes pos

19 sides · captiuos exinde liberabis - et a iugo seruitutis absolues ${ }^{37}$;

20 si quis in conspectu uestro uenerit · peregrinum se esse non

21 sentiat; cum iuuenibus ioca ${ }^{38} \cdot$ cum senibus tracta .' si uis reg-

22 nare .'/ nobilis iudicari ${ }^{39}$.

\section{Translation}

What follows is provided here as orientation for the historiographical overview which follows. The edited text on which it depends is justified in the critical commentary, and printed before the interpretive conclusion.

2. Bishop Remigius, to the lord, distinguished and by his merits magnificent, King Clovis.

[1] The important news has reached us that you have undertaken the waging of another war; it is not a novelty, for you have been just as your kin always were. This must be done first of all, so that the judgement of the Lord should not waver from you, when on account of your merit - in fact, through the industry of your humility - it has reached the height of the peak and the summit. As people say, the action of a man is what is judged.

[2] You should summon advisers to you who can embellish your reputation, and your favour should be moral and honest. You will defer to your bishops and always have recourse to their advice, for if you are on good terms with them your province can fare better. Rouse

uellis $c^{i} G^{i} G^{i i} M^{i} M^{i i}$.

pateat $F S$.

quascunque $F S G^{i} G^{i i} M^{i i}$.

absoluas $c^{i} G^{i} G^{i i} M^{i} M^{i i}$.

jocare $S$.

iudicare $c^{i} G^{i} G^{i i} M^{i} M^{i i}$. 
your citizens, relieve the afflicted, support widows, look after orphans, if it is possible bring them up, in order that everyone love as well as fear you.

[3] Let justice issue forth from your mouth: nothing should be looked for from the poor or foreigners, any more than you should be willing to accept gifts or anything else. Let your headquarters stand open to everyone, so that no one should depart from there sorrowful. Whatever paternal wealth you possess, you will free captives with it and release them from the yoke of servitude. If anyone come before you, let him not feel that he is a stranger. Jest with the young, converse with the old, if you wish to be judged to reign nobly.

\section{Historiography}

In the early $9^{\text {th }}$ century, three scribes copied a unique selection of letters into the first thirty folios of BAV, Pal. lat. 869, making careful efforts to preserve the text of their exemplars. ${ }^{40}$ Subsequently labelled Epistolae Austrasicae (henceforth EA) by Wilhelm Gundlach, they are rich sources for $6^{\text {th }}$-century Gaul. ${ }^{41}$ Beneath the finit is a high medieval note assigning the codex to the Carolingian monastery of Lorsch - one of its librarians compiled these Austrasian letters from materials which he found at Trier. ${ }^{42}$ The compiler made no comment on the place of the four letters of Remigius in the collection, but he gathered them at the beginning, as if important. While the earliest title given to the assemblage (by a much later hand) is Liber epistolarum, it is interesting to note that a still later hand wrote Epistolae Remigii et aliorum at the head. ${ }^{43}$ These letters may also be in chronological order: $E A$ 1, dated by Gregory of Tours to 496 or so, $E A 3$, after the death of Clovis in 511, and $E A 4$, seemingly late

40 See now G. Barrett, G. Woudhuysen, Assembling the Austrasian Letters at Trier and Lorsch, in EME, 24, 1, 2016, pp. 3-57, for what follows.

41 W. Gundlach, Die Sammlung der Epistolae Austrasicae, in NA, 13, 1, 1887, pp. 367-8.

42 BAV, Pal. lat. 869, fol. 30v; cf. B. Bischoff, Die Abtei Lorsch im Spiegel ihrer Handschriften, $2^{\text {nd }}$ ed., Lorsch, 1989, pp. 126-7.

43 BAV, Pal. lat. 869, fols. 1r, 3r. 
in the episcopacy of Remigius (d. 533). ${ }^{44}$ If so, this would suggest a date between 496 and 511 for $E A 2 .{ }^{45}$ At least two hands have intervened since $c^{i}$ copied our letter, and the first, $c^{i i}$, found it baffling in part. Correcting its grammar and adding punctuation, he was twice at a loss: administrationem uos secundum bellice suscepisse (11. 3-4) and si potius est quam erudies (1. 14). He wrote $\dot{r}$ (require, 'check') in the margin beside both, and dotted secundum bellice and erudies, implying that these words were the problem. Medieval intervention ends with $c^{i i i}$, who added a superscript plea, 'would that the mentalité of kings and priests were so today', referring to 11. 10-13: to him, the moral content of the letter was its most notable feature.

\section{Early Modern Diversity}

Marquard Freher produced the first edition of the $E A$ in 1613 under the pedestrian title Epistolae Francicae, having discovered them in the Bibliotheca Palatina at Heidelberg. ${ }^{46} \mathrm{He}$ did not offer comment on each letter, but he did emend EA 2, adopting the corrections of $c^{i i}$, clarifying the adage actus hominis probatur (1.8) by supplying ex fine ('by the outcome'), and adding rei before bellice - the resulting phrase is standard usage for military matters, and his addition, perhaps an expansion of $\dot{r}$, far from radical. Freher seems to have related the letter to a campaign of Clovis, and one in particular, since he appended to it a letter from the Ostrogothic king Theoderic advising mercy toward the blasted survivors of the Alamannic war. ${ }^{47}$ Until the $19^{\text {th }}$ century he remained alone in having consulted the manuscript; after his edition, EA 2 set off on a lonely journey through the commentaries of disputatious scholars.

44 Gregory of Tours, DLH, in B. Krusch, W. Levison (ed.), Gregorii Episcopi Turonensis Libri Historiarum X. MGH SSRM I.1, $2^{\text {nd }}$ ed., Hanover, 1951, II.30-31.

45 On the chronology of the EA, see Barrett, Woudhuysen, esp. pp. 44-5.

46 M. Freher, Epistolae Francicae, in Corpus Francicae Historiae Veteris et Sincerae, Hanover, 1613, pp. 182212.

47 Freher, pp. 184-5; Cassiodorus, Variae, in Å.J. Fridh (ed.), Variarum Libri XII, in Å.J. Fridh and J.W. Halporn (eds.), Magni Aurelii Cassiodori Senatoris Opera, Pars I. Variarum Libri XII. De Anima. CCSL 96, Turnhout, 1973 , II.41. 
First port of call came in 1628, in an unusually full municipal history of Melun. Like Freher, the erudite jurisconsult Sébastien Rouillard did not date the letter, but understood it to announce a 'levée d'armes', observing that with its counsel the pious Clovis terminated his life in glory and honour. ${ }^{48}$ Jacques Sirmond was the earliest editor to comment explicitly on the context of EA 2, printing it between the Council of Agde (506) and the 'letter of Clovis to the bishops' (which he dated to 507), with a gloss: 'Encouraging letter, when the king was readying himself for the Gothic war'. ${ }^{49}$ He was perhaps fortified by its several points of similarity to the letter of Clovis, in which the king provides for the security of Church property and dependants and the release of captives in the aftermath of his campaign against the Visigoths in 506/7, and he made his case by way of emendation, modifying secundum to secundam in agreement with administrationem. ${ }^{50}$ Remigius was exhorting Clovis to go to war once again, this time with the Visigoths, since Gregory of Tours records that his first was against the Burgundians. ${ }^{51}$ Adrien de Valois tacitly endorsed this implicit argument: Remigius seemed to mean that Clovis had been delegated supreme command of another campaign by the Franks in arms. ${ }^{52}$ Delegated, he said - Jean le Laboureur eagerly seized on the word choice, which revealed that kingship was hereditary but generalship elective amongst the Salian Franks. ${ }^{53}$ This Clovis, for Guillaume Marlot, was a Christian crusader, urged by Remigius to sally forth once more against the Arian Visigoths. ${ }^{54}$ And yet when Thierry Ruinart included the text of Freher in his edition of Gregory of Tours, as a call to respect ecclesiastical property during the Visigothic war, he did not adopt

48 S. Rouillard, Melun, ou Histoire de la ville de Melun, Paris, 1628, pp. 165-7; repr. in Épistre de saint Rémy, au roy Clovis, premier chrestien, pour bien régner, Paris, 1825.

49 J. Sirmond, Remigii Episcopi Remorum Epistola II, in Concilia Antiqua Galliae, 3 vols., Paris, 1629, 1, p. 175; cf. J.-E. Taraut, Annales de France, Paris, 1635, p. 150; S. de Sainte-Marthe, L. de Sainte-Marthe, Gallia Christiana, 4 vols., Paris, 1656, 1, p. 478.

50 Clovis, Ep ad episcopos, in A. Boretius (ed.), Capitularia Regum Francorum I. MGH, Hanover, 1883, pp. 12.

51 Gregory of Tours, DLH, II.32.

52 A. de Valois, Rerum Francicarum Libri VIII, 3 vols., Paris, 1646-58, 1, p. 316.

53 J. le Laboureur, Histoire de la Pairie de France et du Parlement de Paris, London, 1740 [1664], p. 177.

54 G. Marlot, Metropolis Remensis Historia, 2 vols., Reims, 1666-79, 1, p. 163. 
secundam despite situating it before the letter of Clovis. ${ }^{55}$ Sirmond, without his foundation: a phenomenon with a history almost as long as the interpretation of the text itself.

With the $18^{\text {th }}$ century, early Frankish history became central to public debate about the position of the French monarchy vis-à-vis its aristocratic subjects, and discussion of EA 2 began in earnest. ${ }^{56}$ The main historical issue in political argument was the origin of Frankish power in Roman Gaul, and proposed dates for the letter started to drift earlier in the reign of Clovis, that defining epoch. René-Aubert Vertot read Sirmond, and he too identified a combination of the dignity of king with an appointment as general; Remigius was saluting Clovis on his taking charge of the army just like his ancestors. ${ }^{57}$ Indeed, M. le comte de Boulainvilliers contended (posthumously) in 1727 that he had founded the Frankish monarchy, inheriting kingship of the Ripuarian Franks from his father Childeric and soon after being elected general of the Salian Franks. He cited the letter, in a reprint of Freher, as congratulations to Clovis on the election, and his argument led him to wonder whether it might in fact date to the first years of his reign, even if he would then have been pagan. The count was altogether more certain that the Franks (a free military class who under their elected ruler had conquered Gaul with its punitive Roman fiscal burdens) were entitled to tax exemption and other rights; so too were their descendants, the French nobility, of which he found himself, incidentally, to be a member. ${ }^{58}$

In 1734 came the counterblast of the abbé Dubos, who struck out on his own with a distinctly loose translation of the same text of the letter. He deduced that Clovis had inherited the title of magister militum from Childeric, rendering the opening line: 'We learn by common report that you are in charge of the administration of the affairs of war, and I am not surprised

55 Ruinart (ed.), cols. 1326-7, with 92, 95.

56 See I. Wood, The Modern Origins of the Early Middle Ages, Oxford, 2013, pp. 19-41; C. Cheminade, Histoire et politique dans L'espirit des lois: Montesquieu, Dubos et Saint Rémi, in M. Porret, C. Volpilhac-Auger (ed.), Le temps de Montesquieu, Geneva, 2002, pp. 345-61.

57 R.-A. Vertot, Dissertation dans laquelle on tâche de démesler la véritable origine des François par un paralelle de leurs mours avec celle des Germains, in ML, 2, 1717, p. 628; cf. H.-P. Limiers, Annales de la Monarchie Françoise depuis son Établissement jusques à présent, 2 vols., Amsterdam, 1724, 1, p. 7.

58 A.G.H.B. de Boulainvilliers, Histoire de l'ancien gouvernement de la France, 3 vols., The Hague, 1727, 1, pp. 17-8; cf. J. de Caulet, Lettre II. De Honore et Cultu Dei, Paris, 1751, pp. 164-6, 174-6. 
to see you be what your forefathers have been'. With Boulainvilliers, he situated EA 2 at the accession of Clovis in 481, when he was still pagan and before Remigius was his subject, but held in contrast that in the late $5^{\text {th }}$ century northern Gaul remained under Roman administration, by subordinates of the praetorian prefect. Clovis was king only at Tournai, but wielded military authority throughout his prouincia as magister militum, ingeniously explaining why the advice applied so widely and his praetorium should be open to all; beneficium tuum (11. 9-10) was a polite nod to the conquests of Chlogio, putative ancestor of Clovis, which Remigius pretended were held in benefice from the emperor. This technical distinction between the beneficium and the prouincia of Clovis explained how he could be told to maintain good relations with bishops - in the plural: evidently there was more than one in his province - yet also to consult with his 'lords, i.e., with the Franks', loyal to him as king. Dubos detected no Christianity in the letter, only moral advice, in marked contrast to the explicitly religious EA 1 . The Franks, it turned out, had not subjected the Gallo-Romans at all, but been absorbed into the absolutist framework of the Roman state, to which the French monarchy was grateful heir. ${ }^{59}$

This is certainly original, and comparison with Sirmond shows the diversity of interpretation which can hinge on a slight difference in text allied to a broad divergence in interest. Dubos became a point of (substantially hostile) departure for intellectuals in the ensuing firestorm of controversy. Antoine Rivet de La Grange discreetly opposed him, defining EA 2 as counsel on Christian rule marked by a 'vigueur épiscopale' and sent in 506 on the eve of war. ${ }^{60}$ Étienne-Lauréault de Foncemagne, meanwhile, probed the inner torment of Boulainvilliers concerning an early date for the letter and the paganism of the king at that time.

59 J.-B. Dubos, Histoire critique de l'établissement de la monarchie françoise dans les Gaules, 3 vols., Amsterdam, 1734, 2, pp. 269-79; cf. J. Liron, Singularités historiques et littéraires, 4 vols., Paris, 1738-40, 1, pp. 49-102; C.J.F. Hénault d'Armorezan, Histoire critique de l'établissement des Français dans les Gaules, 2 vols., Paris, IX/1801 [1738], 2, pp. 261-2.

60 A. Rivet de La Grange, Histoire literaire de la France, 3, Paris, 1735, pp. 158-63; cf. J. Longueval, Histoire de l'Église Gallicane, 8 vols., Paris, 1730-34, 2, pp. 286-7; Gallia Christiana in Provincias Ecclesiasticas Distributa, 9, Paris, 1751, cols. 10-13. 
He declared that it must postdate the baptism of Clovis, for Remigius would only have praised news of war with the Arian Visigoths as a rumor magnus, and that it could not describe his election as general (nor support an elective monarchy), since he had inherited that title from his parentes. ${ }^{61}$ René Biet aligned himself with the nay camp, shooting back that the system of Dubos did not 'conform to History', for EA 1 and 2 both addressed Clovis as king and cited his kingdom (manet uobis regnum administrandum, 'there remains for you a kingdom to be administered', paralleling administrationem). The key here was secundum, which situated the text after the conquest of Thuringia and indicated some sort of association of Clovis and family with the region. ${ }^{62}$ Gilbert-Charles Le Gendre, similarly, could scarcely persuade himself that 'such bizarre sentiments' had been 'published seriously' by Dubos; everyone knew that EA 2 referred to a second war. Sirmond was right: it patently postdated the conversion of Clovis and concerned the prouincia conquered by his Franks, over which he dispensed sovereign justice from his praetorium, and where the Empire had no business appointing officials of any kind. ${ }^{63}$

Yet no one expected the intervention of Jacques Ribauld de La Chapelle, a savant who 'does not appear to have been influenced by the innovative ideas of his times' ${ }^{64}$ He held that Remigius was applauding Clovis on becoming praetorian prefect of Gaul, including Burgundy, on top of his day job as magister militum, and translated Sirmond: 'you hold the second rank in the Empire by administration of the affairs of war'. Childeric, Merovech, and perhaps others had held this position, Clovis had just converted as a youth, and Remigius was counselling him on how to maintain his commission; abusing all opposing arguments, he declined to specify a date of appointment. ${ }^{65}$ Bedlam. When Martin Bouquet reprinted Freher, he elected just to delete

61 É.-L. de Foncemagne, Examen critique d'une opinion de M. le Comte de Boulainvilliers, sur l'ancien gouvernement de la France, in $M L, 10,1736$, pp. 528-32; cf. A.-P.-D. de Gomicourt, Dissertation Historique et Critique pour servir à l'Histoire des premiers tems de la Monarchie Françoise, 2 vols., Colmar, 1754, 1, pp. 22-30.

62 R. Biet, Dissertation sur la véritable époque de l'établissement fixe des Francs dans les Gaules, Paris, 1736, pp. 33-6.

63 G.-C. Le Gendre, Des antiquités de la nation et de la monarchie françoise, Paris, 1741, pp. 574-83.

64 L. Virlogeux, Si Gannat m'était conté. Profils et silhouettes, Nonette, 2005, p. 28.

65 J. Ribauld de La Chapelle, Dissertations sur le règne de Clovis, Paris, 1741, pp. 19-34. 
magnus and insert the heading 'Letter of St Remigius to Clovis before the Gothic war, by which he encourages him to consult the bishops', again accepting the reading of Sirmond without his emendation, while gesturing to Dubos on Clovis and Childeric as magistri militiae. ${ }^{66}$

Enter Montesquieu ('Is he relevant?' ${ }^{67}$ ). Charles-Louis de Secondat sternly rejected the Dubos line in 1748, reserving signal vehemence for the notion that Clovis had been invited to govern the Gallo-Romans, and in this connexion trained his fire on EA 2. The imperial dignities which the abbé imagined that Clovis had been awarded were his inventions; the letter merely congratulated the king on his accession to the throne. 'When the object of a piece of writing is known,' he asked, 'why give it one which is not there?' ${ }^{68}$ Whereupon Ribauld de La Chapelle recanted his earlier rash views, reaching the inevitable reductio ad falsum of source criticism down the ages: the text could not be made to fit any point in the reign of Clovis, its composition was beneath Remigius (master stylist of his day), its hectoring tone was absurd for a king, and so 'this letter has been fabricated by some bad writer' ${ }^{69} \mathrm{He}$ did not vouchsafe whom. LouisJules Mancini-Mazarini resourcefully opened a new front in the interpretive struggle by taking secundam as 'fortunate' instead of 'second', making EA 2 a bit of cheerleading on the defeat of Syagrius in 486. Dubos was correct in his dating, but for the wrong reasons; Clovis was a conquering king, not an imperial quisling. ${ }^{70}$ A critic for the Mercure de France could take no more, and waded into the debate to refute both systems of Ribauld de La Chapelle: the first availed itself of 'pretend evidence', and as for the second all late Latin was bad, the other prose and 'pitiable' poetry of Remigius included, while his manners were unimpeachable. Why could no one see that the 'natural sense' of beneficium was 'baptism'? Remigius was praising Clovis

66 Bouquet (ed.), 4, pp. 51-2.

67 M. Vale, Custom, Combat, and the Comparative Study of Laws: Montesquieu Revisited, in P. Dresch, H. Skoda (ed.), Legalism: Anthropology and History, Oxford, 2012, p. 261.

68 Baron de La Brède et de Montesquieu, De l'esprit des loix, 2 vols., Geneva, 1748, 2, p. 473; cf. A.M. Cohler, B.C. Miller, H.S. Stone (ed.-transl.), Montesquieu: The Spirit of the Laws, Cambridge, 1989, p. 661.

69 J. Ribauld de La Chapelle, Dissertations sur l'origine des Francs, Paris, 1748, pp. 155-74.

70 M. le duc de Nivernois, Mémoire sur l'indépendance de nos premiers Rois par rapport à l'Empire, in ML, 20, 1753, pp. 167-70. 
circa 496 for retaking (secundum) the reins of government after his post-baptismal vacation. ${ }^{71}$ Yet to Louis-Gabriel Du Buat-Nançay the contrary truth was equally plain: Clovis was king by heredity, hence non est nouum, as well as imperial $d u x$ by extraordinary nomination. ${ }^{72}$

When the Bollandists produced the volume of Acta Sanctorum containing Remigius in 1765, they reprinted Sirmond but refined his arguments. Constantine Suysken flagged another point where the letter seemed corrupt - ubi tui meriti (1. 6) - and imaginatively proposed a tuo exercitu ('by your army'), while emending si potius est quam erudies to Sic potius illos erudies ('In this way, rather, you will teach them'). On the date, he supposed that it had been situated before the Visigothic war because of the 'second administration', numbering perhaps from the Alamannic campaign, and the congruity of theme with the letter of Clovis. Yet he maintained that rumor suggested report of victory as much as approaching war, and secundam could mean 'successful' just as well. Suysken interpreted the first sentence: 'We have understood from a momentous report that you have succeeded in the administration of matters of war which you have undertaken'. His parents had done so too, and the Lord enabled his victories; the advice suited a prince taking over a new conquest. ${ }^{73}$ Dubos, however, continued to provoke. JeanJacques Garnier felt that the letter, citing only the royalty to which Clovis succeeded by birth and election, was 'equivocal' evidence for such 'temerity', while Pierre Bouquet countered that it recorded the Germanic 'confederates' electing the Salian king as their general. ${ }^{74}$

Comment tailed off in the later $18^{\text {th }}$ century at an impasse, most conceivable positions on EA 2 essayed and all sides entrenched. With the French Revolution, the debate, centred on

71 Dissertation sur une Lettre de Saint Remi à Clovis, in Mercure de France, dédié au Roi, June 1756, pp. 13755; Suite de la dissertation sur une Lettre de Saint Remi à Clovis, in Mercure de France, dédié au Roi, July 1756, 1, pp. 149-63.

72 L.-G. Du Buat-Nançay, Les origines, ou l'ancien gouvernement, de la France, de l'Allemagne et de l'Italie, 4 vols., The Hague, 1757, 1, pp. 15-6.

73 Gesquier et al. (ed.), pp. 91-2.

74 J.-J. Garnier, Traité de l'origine du gouvernement françois, Paris, 1765, pp. 15-6; P. Bouquet, Lettres provinciales, ou examen impartial de l'origine, de la constitution, et des révolutions de la monarchie françoise, The Hague, 1772, pp. 58-9. 
the import of the letter for royal authority and noble privilege, lost its urgency. ${ }^{75}$ Dubos gained an illustrious champion in François-Marie Arouet, dit Voltaire, who charged Montesquieu with 'grand tort' and self-assuredly translated administrationem rei bellice suscepisse as magister militum or 'colonel général'. ${ }^{76}$ Edward Gibbon, meanwhile, regarding the Barbarian West from his Olympian heights, disapprobated the epistolary efforts of Remigius, but made no use of the second of them despite his intimate acquaintance with French erudition. ${ }^{77}$ Jean-Marie Viallon, in the last year of the Ancien Régime, drew out what Montesquieu had left implicit: the letter was written to Clovis not in 486 but 481, on his appointment not as magister militum but dux, reflecting not relations with the Romans but the Franks as a free people. ${ }^{78}$ Since there was no longer need for the aid which EA 2, dated early, could bring the arguments of the $18^{\text {th }}$ century, Sirmond - qualified - regained supremacy, at least for a moment. The letter as witness to a $6^{\text {th }}$ century warrior Clovis was by now a venerable strand of interpretation, but it had received no systematic exposition so long as a text from the 480s was more useful: paradoxically, this less vigorously held position became the point of departure for $19^{\text {th }}$-century scholars. In that same fateful year of 1789, when the Maurists commenced work on an abortive edition of Sirmond, they saw only a need to allow for a multiplicity of possible motivations for Clovis at war. ${ }^{79}$ This began a trend which culminated in Thomas-Marie-Joseph Gousset, archbishop of Reims, printing the letter in his history of the province with a date of circa 507, headed 'On how to rule' and glossed: 'On the war which Clovis began against the Goths, who still occupied part

\footnotetext{
75 See in general I. Wood, The Panthéon in Paris: lieu d'oubli, in H. Reimitz, B. Zeller (ed.), Vergangenheit und Vergegenwärtigung. Frühes Mittelalter und europäische Erinnerungskultur, Vienna, 2009, pp. 93-102; H. Williams, Saint Geneviève's Miracles: Art and Religion in Eighteenth-Century Paris, in French History, forthcoming.

76 Voltaire, Loi; Esprit des lois, in N. Cronk, C. Mervaud (ed.), OCV 42B. Questions sur l'Encyclopédie, par des amateurs, 7, Oxford, 2012, pp. 116-7; Voltaire, Commentaire sur L'esprit des lois, in R. Granderoute, S. Mason (ed.), OCV 80B. Writings of 1777-1778, 1, Oxford, 2009, p. 427.

77 E. Gibbon, D. Womersley (ed.) The History of the Decline and Fall of the Roman Empire, 3 vols., London, 1994 [1776-88], 2, p. 458, n. 27.

78 J.-M. Viallon, Clovis-le-grand, premier roi chrétienne, fondateur de la monarchie française, Paris, 1788, pp. 193-202.

79 Conciliorum Galliae, cols. 827-8.
} 
of the Gauls'. ${ }^{80}$ When 'God's plagiarist' Jacques-Paul Migne moved to include EA 2 in his Patrologia Latina, he duly combined these notes with the text of Sirmond. ${ }^{81}$

Jules de Pétigny checked the incipient consensus in 1844, remarking of his predecessors that, 'applying to the barbarian kingdoms of the $5^{\text {th }}$ century the monarchical ideas of the $17^{\text {th }}$, they have been unable to grasp the simultaneous existence of the power of the Frankish kings and the sovereignty of the Empire'. ${ }^{82}$ Reviving the Dubos gambit, he concluded that Ricimer, late imperial generalissimo, had made Childeric magister militum, and Clovis had inherited the title. Childeric and Remigius acceded around the same time and must have been allies; naturally Remigius wrote to Clovis when he succeeded. Pétigny, translating, conjectured that secundum was an error for the adverb 'happily', discreetly dropped si potius est quam erudies altogether, and altered nobilis (1.22) to a nobilibus ('by nobles'), noting that almost every word merited a commentary. He believed that the tone was one of not a subject but 'a father talking to his son, a master instructing his pupil'; no word of kingship, just felicitations to an officer of the Empire on his promotion, so the ciues (1. 13) were his Roman citizens, and the sacerdotibus (1. 10) his bishops, not pagan priests as some had scandalously supposed. The trump? The term prouincia, of course: 'always employed by Latin authors for the territory over which a Roman magistrate exercised his jurisdiction'. This was a letter about land and land management; in accordance with Dubos (uncited), beneficium must stand for 'military benefice'. ${ }^{83}$

80 T.-M.-J. Gousset, Les actes de la province ecclésiastique de Reims, 4 vols., Reims, 1842-4, 1, p. 2 ; $c f$. C.C. Fauriel, Histoire de la Gaule Méridionale sous la domination des Conquérants Germains, 4 vols., Paris, 1836, 2, p. 55; J.-F. Grégoire, F.-Z. Collombet, Euvres de C. Sollius Apollinaris Sidonius, 3 vols., Paris, 1836, 2, pp. 476-8; J. Guadet, N.-R. Taranne, Histoire ecclésiastique des Francs, par Georges Florent Grégoire, évêque de Tours, en dix livres, 4 vols., Paris, 1836-8, 1, p. 247, n. 3; J.-M. Pardessus, Diplomata, Chartae, Epistolae, Leges, Aliaque Instrumenta ad Res Gallo-Francicas Spectantia, 2 vols., Paris, 1843, 1, no. 76, p. 53; T. Armand, Histoire de Saint Rémi, Paris, 1846, pp. 129-32; A.-F. Ozanam, La civilisation chrétienne chez les Francs, Paris, 1849, pp. 339-40; H. Martin, Histoire de France, 17 vols., Paris, 1855-60, 1, p. 410; J.-E. Bimbenet, Des conciles d'Orléans, in Revue Critique de Législation et de Jurisprudence, 23, 13, 1863, pp. 298-302.

81 Migne (ed.), PL, 65, cols. 965-8; and see R.H. Bloch, God's Plagiarist: Being an Account of the Fabulous Industry and Irregular Commerce of the Abbé Migne, Chicago, 1994.

82 J. de Pétigny, Études sur l'histoire, les lois, et les institutions de l'époque mérovingienne, 3 vols., Paris, 184351,2, pp. 355.

83 De Pétigny, 2, pp. 362-3, 367-8; cf. A. Digot, Histoire du royaume d'Austrasie, 4 vols., Nancy, 1863, 1, pp. 164-5. 
The wind of change was blowing, in spite of some obstruction. Georg Waitz dismissed Pétigny out of hand: sacerdotibus were bishops and would not be tuis if the king were a pagan, and if Clovis were a 'military official' his praetorium could hardly be 'open to everyone', could it, since his jurisdiction would be confined to the soldiery. ${ }^{84}$ The identity of these sacerdotibus had emerged as another point of contention, addressed shortly thereafter in a courageous new reading of the letter. Wilhelm Junghans scorned all talk of magister militum, for although the text was corrupt in places, had Remigius wanted to say some such he would have done so. In a broad endorsement of Pétigny, he homed in on sacerdotibus tuis: their presence demonstrated that the letter had been written after the baptism Clovis in 496, and yet he was then far from an inexperienced king. To the discerning student there could be only one solution. The addressee was not Clovis at all, but one of his sons who came to the throne when Remigius was still alive, the likely culprit for this embarrassing substitution a copying error in the heading. ${ }^{85}$

When EA 2 landed on the desk of Albert Lecoy de La Marche in 1866, it occupied a position of critical contradiction. Freher, alone in having studied the manuscript, had foresworn to opine on its meaning, while not all who supported Sirmond accepted his emendation, and the fullest commentary had come from those, like Dubos, most remote from the mainstream. Everybody emended, often via translation - so much more forgiving than the original - or else by positing some appalling blunder. Lecoy de La Marche, however, proposed to approach the letter in and of itself. Believing the original lost, he worked from Freher and his serial reprintings, which seemed spontaneously to adopt and defend a dating of 507; he knew that Sirmond had advanced the idea but could not see why. How could this be the date of the letter if Remigius, whose vita recorded an intimate association with Clovis, heard of the expedition by rumour? The vexatious administrationem rei bellice was neither good Classical nor

84 G. Waitz, Deutsche Verfassungsgeschichte, 8 vols., Kiel, 1847-88, 2, pp. 42-4.

85 W. Junghans, Die Geschichte der fränkischen Könige Childerich und Chlodovech, Göttingen, 1857, pp. 1412; W. Junghans, G. Monod (transl.), Histoire critique des règnes de Childerich et de Chlodovech, Paris, 1879, pp. 143-4. 
acceptable late Latin for 'military campaign', and even if it were taken with secundum as a second expedition by Clovis, it would not be the Visigothic war, his fourth or fifth. As for the rest: 'are these instructions for war or peace?' Childeric had plundered Christians, and Remigius would surely not invoke him (one of the parentes) as an example for his convert son, while parallels with the letter of Clovis were unsound, since that treated Church privileges, conspicuously absent here. Both missives spoke of ransoming prisoners, but this implied only that $E A 2$ should pre-date $507 .^{86}$

Sirmond so dismissed, Lecoy de La Marche was equally ill at ease in the company of Dubos and his ilk. There was quite simply no evidence that Childeric or any of the ancestors of Clovis had been magistri militum. Dubos had warped words to his system, reducing Clovis to a mere functionary of the Empire: this he was manifestly not amidst its decaying remnants. Pétigny was more plausible, but the sacerdotibus tuis were a grave objection, since these were certainly not pagan priests and Clovis had no bishops in 481. Refusing to retire from the field, Lecoy de La Marche argued that secundum did mean 'happily', but adjectivally. Remigius was congratulating Clovis, 'you have conducted a successful war'; the letter must have been written in its aftermath, instructions on how to treat subjects acquired on campaign. The paternal tone ruled out Vouillé in 507, and other wars had not gained him new ciues or a new prouincia, nor need the letter postdate the conversion of Clovis, as it lacked Christian allusion. His early years seemed most likely - not 481 but 486, after the battle of Soissons, when he had made himself master of northern Gaul. ${ }^{87}$ All the problems seemed to fall away.

Lecoy de La Marche, by his careful review of the options, put discussion of EA 2 on a new footing, clearing the ground for further study. Alas imperfectly: no positive reference in the letter proved his date, and how could domini iudicium (11. 5-6) not be Christian? Aid was

\footnotetext{
86 A. Lecoy de La Marche, De l'interprétation d'une lettre de S. Rémi à Clovis, in BECh, 27, 1866, pp. 60-66. 87 Lecoy de La Marche, pp. 70-73.
} 
at hand (albeit not acknowledging his work). Jean-Louis-Alphonse Huillard-Bréholles, noted diplomatist, delivered himself of a case for an early date through reading administrationem uos secundae, Rex, Belgicae suscepisse ('you have undertaken the administration, king, of Belgica Secunda'), a change with a long future, though without credit to its author. He also dealt with 'the judgement of the Lord' in a less happy solution, this astonishing chimera:

Above all you must act such that the Emperor (Dominus) does not go back on the decision (judicium) which he has made about you, now that the rights of your services (tui meriti jus for tui meriti qui), thanks to your actions and ability (utilitatis tuae for humilitatis tuae), have attained access to his supreme authority (ad summum culminis pervenit).

This is pretty desperate stuff, but it supported an early date, here 488, buttressing theories as to how the Franks had, or rather had not, conquered Gaul and its peoples. ${ }^{88}$

Dubos was back. Polynomious antiquary C.A. Moët de La Forte-Maison ('membre de plusieurs sociétés savantes') invoked him to the effect that the letter concerned some imperial appointment made before Clovis went to war against Syagrius, providing another translation which might charitably be called approximate. ${ }^{89}$ When Auguste Vitu, man of letters, treated the early Franks, he too dated $E A 2$ to just after 481, feeling no special imperative to prove his proposition that it recorded the military rank which Clovis and his ancestors held from the Empire. ${ }^{90}$ The new edition of the Maurist history of France consequently qualified Rivet de La Grange, cautiously relating the letter to the demise of Childeric and the 'military acclamation' of his son. ${ }^{91}$ At this point the narrative takes on an element of the grotesque: amongst the 27,000 forgeries produced by Denis Vrain-Lucas before his celebrated trial in 1869 is a bogus note from François Rabelais to Julius Caesar Scaliger. The great satirist reports his discovery of a codex at Saint-Florentin de Bonneval - once Carolingian abbey, now psychiatric hospital - and

88 J.-L.-A. Huillard-Bréholles, Essai de restitution de l'une des lettres adressées par saint Remi à Clovis, in Comptes rendus des séances de l'Académie des Inscriptions et Belles-Lettres, 14, 1870, pp. 283-7.

89 C.A. Moët de La Forte-Maison, Les Francs, leur origine et leur histoire, 2 vols., Paris, 1868, 2, pp. 122-5.

90 A. Vitu, Histoire civile de l'armée, Paris, 1868, p. 31, n. 2.

91 P. Paris (ed.), Histoire literaire de la France, 3, rev. ed., Paris, 1866, p. 729. 
encloses $E A$ 2, asking the great humanist for elucidatory comment. A genuine letter within a fake, it turns out on close inspection to be the text of Freher, bastardized, a curiosity not only attesting the progress of the 'prince of forgers' through the famous figures of French history, but also reflecting the stubborn resistance of the correspondence of Remigius and Clovis to comprehension. ${ }^{92}$

Numa Denis Fustel de Coulanges wrote a few more sober pages of his own on the letter, dating it to circa 481 . He thought that administrationem and parentes described Clovis coming into the military offices held by his ancestors, and the tone seemed to suit a young prince best; the lack of Christian content (unlike $E A 1$ ) and mention of military victory was striking, while the troublesome sacerdotes were simply Christian priests serving in a Frankish federate army. Fustel de Coulanges believed that Remigius understood Clovis as a military man, subordinate to the emperor, hence beneficium - 'a commission, a precarial and revocable possession' - and prouincia, although he later effected a partial retreat from this position, allowing that the king could have awarded himself a Roman title. ${ }^{93}$ When the judicious Waitz revisited the scene in 1887, however, he conceded only that 'it remains difficult to determine the time and occasion of writing'. Junghans had been reckless to suggest that the letter was to a son of Clovis, and Lecoy de La Marche merited no response; the identification of Childeric or Clovis as magister militum continued to bemuse him..${ }^{94}$ As the fin de siècle drew nigh, an innocent bystander could be forgiven for thinking that there were two, nay three distinct versions of $E A 2$, so diverse had the accounts of it become. Would historians never be able to agree on its meaning? ${ }^{95}$

92 BnF, NAF 709, fols. 158r-v; H. Clouzot, Les lettres de Rabelais écrites par Vrain-Lucas, in Revue des Études Rabelaisiennes, 10, 1912, no. 12, pp. 223-4; cf. J. Rosenblum (transl.), Prince of Forgers, New Castle, 1998. 93 N.D. Fustel de Coulanges, Histoire des institutions politiques de l'ancienne France, 6 vols., Paris, 1875-92, 1, pp. 381-2, n. 1, 2, pp. 481-8; cf. A.-L.-U. Gasquet, L'empire byzantin et la monarchie franque, Paris, 1888, pp. 124-6.

94 G. Waitz, Deutsche Verfassungsgeschichte, $3^{\text {rd }}$ ed., 6 vols., Kiel, 1880-96, 2, p. 38, n. 2.

95 E. Lavisse (dir.), Histoire de France illustrée depuis les origines jusqu'à la Révolution, 9 vols., Paris, 190011, 2, 1, pp. 96-7; A. Lombard, L'abbé Du Bos. Un initiateur de la pensée moderne, Paris, 1913, pp. 447-8. 


\section{Modern Conformity}

Into this interpretive ferment strode the man from Monumenta. Wilhelm Gundlach has exerted a powerful, though not wholly benign, influence over the text and interpretation of $E A$ 2 through his study of the collection as a whole in 1887 and his edition in $1892 .{ }^{96}$ He rejected administrationem uos secundum bellice suscepisse as written, because secundum, construed as 'a second time', was self-evidently contradicted by coeperis esse, 'you have begun to be'. His inspection - by proxy - of the manuscript revealed no warrant for supplying rei, but an(other) obvious solution presented itself: secundum bellice must be Secundae Belgicae, a breakthrough which he attributed to his collator Ludwig Bethmann. ${ }^{97}$ Gundlach alleged in support that this was not the sole misspelling of Belgicae in the collection (it is), and that case endings were no obstacle because they were often confused in the letters; he also observed that $c^{i i}$ had written require in the margin, so something was amiss. With this slight but significant alteration, the letter clearly dated to 486, when Clovis defeated Syagrius and acquired the province of Belgica Secunda, big news indeed for Remigius, its metropolitan bishop. Gundlach granted but a single difficulty: 'the judgement of the Lord' implied that Clovis was Christian, yet we all know from Gregory of Tours that he was converted and baptized late in his reign, after his defeat of the Alamanni. No matter: Clovis and the Franks were already Christian when they conquered Gaul - so much for Gregory and his 'legendary account'. ${ }^{98}$ Untroubled by the irony of jettisoning a narrative while retaining its chronology, Gundlach printed the meaningless Secundum Belgice in the main text as one of few modifications, and relegated Secundae Belgicae (grammatical, at least) to the apparatus, referring the interested reader to his own work and assigning a date of '486?' to the letter. Master of the field, he marched onward to greater victories.

Gundlach, Die Sammlung, pp. 365-87; Gundlach, Epistolae Austrasicae, pp. 110-53.

Gundlach, Epistolae Austrasicae, p. 110.

Gundlach, Die Sammlung, pp. 380-82. 
Gundlach converted a maddening passage into a datable reference point, fixing $E A 2$ in the late $5^{\text {th }}$ century. This was a time of transition in Gaul from Roman to Germanic (or was it?), deeply contested and politically momentous in an age of competing nationalisms, a struggle in which the Monumenta were far from neutral: SANCTUS AMOR PATRIAE DAT ANIMUM, and all that ${ }^{99}$ Even more, insertion in an $M G H$ text exalted the emendation, occluding the fact that all the changes made had been canvassed before, and turning what had been a perceptible drift in argument toward a date in the 480s into a superficially scientific certainty. Fame beckoned. Paul Viollet promptly cited Gundlach as support for his belief that the letter dated to 481 and Clovis retained the Roman honour with which Childeric had been invested. ${ }^{100} \mathrm{He}$ was rather less confident as to the identity of this dignity, and derided the notion that the letter proved the king to have been Christian, but the text as endowed with a real Roman province - in alignment with beneficium, prouincia, and praetorium - was already beginning to restrict lines of enquiry. Godefroid Kurth, in his mammoth tome on Clovis, knew that both 486 and 507 had partisans, but supposed that Bethmann had actually read Secundum Belgice in the manuscript, ruling out 507. Christianity aside, he plumped for 481: the letter suited a young king better than a veteran who had just overcome a rival. ${ }^{101}$ Albert Hauck was even moved to abjure former acceptance of the Junghans 'evasion', with the proviso that Clovis already ruled much of Belgica Secunda prior to victory over Syagrius and the advice better suited his accession. ${ }^{102}$ Wilhelm Levison was more cautious: accepting 486, he favoured a gradual, internal process of conversion, at any

99 See Wood, Modern Origins, pp. 156-7; D. Knowles, Great Historical Enterprises, London, 1962, p. 71.

100 P. Viollet, Histoire des institutions politiques et administratives de la France, 3 vols., Paris, 1890-1903, 1, p. 185, n. 5; cf. Fustel de Coulanges, 2, pp. 483, n. 3, 485, n. 2.

101 G. Kurth, Clovis, $1^{\text {st }}$ ed., Tours, 1896, pp. 240-43, 612.

102 A. Hauck, Kirchengeschichte Deutschlands, 1, $2^{\text {nd }}$ ed., Leipzig, 1898, p. 580 (cf. $1^{\text {st }}$ ed., Leipzig, 1887, pp. 110, n. 4, 212, n. 1). 
time during which it would have been acceptable for Remigius to post this letter. ${ }^{103}$ Even so, the problematic proposals of Gundlach were soon canonized in works of reference. ${ }^{104}$

J.B. Bury authored one of the last substantive treatments of EA 2 in 1924, confronting and confuting the choices on offer. Offering the text secundum $\uparrow$ belgice, he stated with curt certainty: 'That the word secundum is corrupt is evident, and equally evident that Bethmann's restoration Secunde Belgice is right. This is universally acknowledged and I will waste no words on it'. ${ }^{105}$ Gundlach had dated the letter to 486 and held it to describe a Christian king, but while Bury countenanced the second proposition he repudiated the first, pointing out that 'ecclesiastical tradition' (Gregory of Tours) was unlikely to recast Clovis as a later and looser Catholic. He called out Pétigny and Kurth on their failure to deal with the Christianity of the letter and affirmed that a date of 481 was 'built on a void': Clovis had gained Belgica Secunda in war, not by inheritance. Bury stoutly concluded that the letter postdates 496 and 'teaches us a new and illuminating fact'. Clovis gained power over Roman Gaul in 486:

But he did not at that time make any change in the routine of government and administration. He did not remove the Imperial officials, who were running the province of Belgica Secunda, but told them to 'carry on.' The taxes would naturally go to the king's coffers, so far as they exceeded the expenses of administration, but otherwise the machine was allowed to run, as before, without interference for at least ten years. ${ }^{106}$

Precise administrative continuity begins to emerge here as the dominant theme.

Critical comment on the refashioned EA 2 was increasingly confined to footnotes, and the range of interpretations constricted along with it. Herman Fischer dated the letter to 'the

103 W. Levison, Zur Geschichte des Frankenkönigs Chlodowech [1898], repr. in Aus rheinischer und fränkischer Frühzeit: Ausgewählte Aufsätze, Düsseldorf, 1948, pp. 226-7; cf. F. Dahn, Die Könige der Germanen, 7, 3, Die Franken unter der Merovingen, Leipzig, 1895, p. 190.

104 A. Molinier, Les sources de l'histoire de France des origines aux guerres d'Italie (1494), 6 vols., Paris, 19016, 1, p. 77; W. Wattenbach, E. Dümmler, Deutschlands Geschichtsquellen im Mittelalter bis zur Mitte des dreizehnten Jahrhunderts, Stuttgart, 1904, pp. 121-2; L. Duchesne, Fastes épiscopaux de l'ancienne Gaule, $2^{\text {nd }}$ ed., 3 vols., Paris, 1907-15, 3, pp. 81-2; F. Kauffmann, Deutsche Altertumskunde, 2 vols., Munich, 191323, 2, pp. 118-9.

105 J.B. Bury, The End of Roman Rule in North Gaul, in Cambridge Historical Journal, 1, 2, 1924, p. 198.

106 Bury, The End, pp. 198-200; cf. J.B. Bury, History of the Later Roman Empire, 2 vols., London, 1923, 1, pp. 346-7; J.B. Bury, The Invasion of Europe by the Barbarians, London, 1928, pp. 243-7. 
beginnings of the reign of Clovis', proof that he had inherited the office of magister militum, while Marc Bloch discerned no Christianity (unlike in $E A$ 1), rather a resolve to avoid such; flagging the original text while endorsing its emendation, he joined Kurth in dating it to 481, a record of the early subjection of Belgica Secunda. ${ }^{107}$ Bruno Krusch contributed his coveted endorsement by way of a footnote in the Monumenta house journal of 1928, providing the only explicit reasoning for the emendation: regrettably misled by the inscrutable layout of another $M G H$ edition, he believed Bellica Secunda to be the majority reading for the name of this province in the manuscripts of the Notitia Galliarum (it is not). This Clovis was embarking on a career in the Roman civil service, but need not have been Christian. ${ }^{108}$ When Carlo SilvaTarouca reprinted Gundlach two years later, he added only an obscure note that the province suggested a date of $483 .^{109}$

Dissent was muted. D.A. Stracke keenly reviewed the evidence for 481 and 486, settling without palpable enthusiasm on the earlier while warning that rumor implied a victory farther from Reims than Soissons. ${ }^{110}$ Wolfram von den Steinen was alone in finding little to praise in the editorial output of Gundlach, but nonetheless accepted the Bethmann emendation as 'nonconjecture'. ${ }^{111}$ In the rearguard trailed the doughty Ludwig Schmidt, who at length opted for 482/3: assailing Gundlach, Bury, and Bloch alike, he observed that Clovis was counselled cum iuuenibus ioca ('joke with the young') and must perforce himself be young. The next clause, advising him to 'converse with the old', did not participate in this same logic. As for the Roman language of the text, it was just that, without any specific administrative force; Remigius had

107 H. Fischer, The Belief in the Continuity of the Roman Empire among the Franks of the Fifth and Sixth Centuries, in Catholic Historical Review, 10, 4, 1925, pp. 545-7; M. Bloch, Observations sur la conquête de la Gaule romaine par les rois francs, in Revue Historique, 154, 2, 1927, pp. 165-6, n. 5; cf. A. van de Vyver, La victoire contre les Alamans et la conversion du Clovis, in RBPH, 15, 3-4, 1936, p. 863, n. 1.

108 B. Krusch, Der Bayernname. Der Kosmograph von Ravenna und die fränkische Völkertafel, in NA, 47, 1928, pp. 66-7, n. 4.

109 Silva-Tarouca (ed.), pp. 43-4.

110 D.A. Stracke, Over bekeering en doopsel van Chlodovech, in Ons Geestelijk Erf, 5, 1931, pp. 37-40, n. 127.

111 W. von den Steinen, Chlodwigs Übergang zum Christentum. Eine quellenkritische Studie, in MIÖG. Ergänzungsbände, 12, 1932-33, p. 432, nn. 2-3. 
learned of the conquest of Belgica Secunda by rumour, so Clovis only ruled part of it, around Tournai, amidst other Salian kings and Syagrius. ${ }^{112}$ To a thoughtful Joseph Fischer, the paternal role of Remigius and the position of the Gallic episcopate in the Frankish kingdom were both apparent, making the Christianity of Clovis self-evident, and yet the 'real reason' for the letter remained debatable. ${ }^{113}$ When Floribert Rommel curated a new text of the collection for Corpus Christianorum, however, he contented himself with Gundlach, lightly revised. ${ }^{114}$

As an audacious emendation became the new orthodoxy, the satisfying soup of theories and dates boiled down to a desiccated stock cube of debate over the tenor of $E A 2$ and in which of two years it belonged. The age and religion of Clovis were central: Kurt Aland puzzled over how an obviously Christian letter could have been mailed to a sixteen-year-old who had yet to convert, and reasoned that the king, just like his father, merely sympathized with Christianity in deference to his environs. ${ }^{115}$ J.M. Wallace-Hadrill favoured 481 for this 'patronizing' letter: 'the pagan barbarian will wish to reflect on the advantages of having the Gallo-Roman church on his side'. ${ }^{116}$ A.H.M. Jones took it for granted that Clovis kept the provincial administration intact, while Georges Tessier, in his notable volume on Clovis (and more), could spare no more than a page: "“Great news has reached us", writes the prelate nonchalantly, "you have taken in hand government of Belgica Secunda"'. Whether this could be addressed to a pagan remained unclear, but he cited Bloch approvingly for a date of 486 or so, characteristically wary of undue

112 L. Schmidt, Aus den Anfängen des salfränkischen Königtums, in Klio, 34, 1942, pp. 312-3; cf. L. Schmidt, Das Ende der Römerherrschaft in Gallien (Chlodowech und Syagrius), in Historisches Jahrbuch, 48, 1928, pp. 611-8; F. Vercauteren, Étude sur les civitates de la Belgique seconde. Contribution à l'histoire urbaine du Nord de la France de la fin du III à la fin du XI $I^{e}$ siècle, Brussels, 1934, pp. 44-5; K.F. Stroheker, Der senatorische Adel im spätantiken Gallien, Tübingen, 1948, p. 207.

113 J. Fischer, Die Völkerwanderung im Urteil der zeitgenössischen kirchlichen Schriftsteller Galliens unter Einbeziehung des heiligen Augustinus, Heidelberg, 1947, pp. 265-6.

114 W. Gundlach, F. Rommel (rev.), Epistulae Austrasicae, in H.M. Rochais (dir.), Defensoris Locogiacensis Monachi Liber Scintillarum. CCSL 117, Turnhout, 1957, pp. 408-9.

115 K. Aland, Kirchengeschichtliche Entwürfe: alte Kirche, Reformation und Luthertum, Pietismus und Erweckungsbewegung, Gütersloh, 1960, pp. 29-30.

116 J.M. Wallace-Hadrill, The Long-Haired Kings, London, 1962, p. 166. 
precision. ${ }^{117}$ For Karl Hauck, as the Maurists had implied, the letter presaged the acclamation of Clovis at Tours in 508: a 'mighty, thunderous applause' welcomed his earlier adventus as provincial in EA 2, an interpretation of rumor magnus suggested by the use of rumor populi in the general vicinity of an episcopal acclamation described by a much later text. ${ }^{118}$ Erich Zöllner was amongst the last even to register secundum bellice, only to pronounce its identification as a province 'unanimously accepted' and put the letter in 481 due to its 'didactic tone'. ${ }^{119}$

No defenders remain for a date after 486; there are few discussions of the real textual problems, only glosses on a single interpretation. The letter has been solved, proof - oblique perhaps - that Clovis took over the Roman province of Belgica Secunda, as a Roman province, early in his reign, a rare stable axis on which to fix the confused history of the late $5^{\text {th }}$ century in Gaul. ${ }^{120}$ For Eugen Ewig, indeed, it is the key to the otherwise mysterious rise of the kings of Tournai: at first subordinate to the legitimate representatives of Roman authority in northern Gaul - Aegidius, Syagrius, and the comes Paul - their acquisition of administrative office in Reims gave both Childeric and Clovis a legitimacy of their own to develop under favourable circumstances. ${ }^{121}$ This period of transition, in other words, remains as crucial to the late antique

117 A.H.M. Jones, The Later Roman Empire, 284-602. A Social, Economic, and Administrative Survey, 3 vols., Oxford, 1964, 1, p. 261; G. Tessier, Le baptême de Clovis, Paris, 1964, pp. 82-4.

118 K. Hauck, Von einer spätantiken Randkultur zum karolingischen Europa, in Frühmittelalterliche Studien, 1 , 1967, pp. 32-3, n. 77; cf. Vita Sollemnis Episcopi Carnoteni, in B. Krusch, W. Levison (ed.), Passiones Vitaeque Sanctorum Aevi Merovingici VII. MGH SSRM VII, Hanover, 1920, c. 5.

119 E. Zöllner, Geschichte der Franken bis zur Mitte des 6. Jahrhunderts, Munich, 1970, pp. 45-6; cf. E.M. Wightman, Gallia Belgica, London, 1985, pp. 304-5.

120 See A. Lippold, Chlodovechus, in Paulys Realencyclopädie der classischen Altertumswissenschaft, Supplementband XIII, Stuttgart, 1973, col. 142; R.W. Mathisen, The Ecclesiastical Aristocracy of FifthCentury Gaul: a Regional Analysis of Family Structure, Ph.D. Thesis, University of Wisconsin-Madison, 1979, pp. 533-4, n. 1502; H.H. Anton, Franken, III. Historisches, in Reallexikon der Germanischen Altertumskunde, 9, Berlin, 1995, col. 423; R. Kaiser, Die Franken: Roms Erben und Wegbereiter Europas?, Idstein, 1997, no. 9, pp. 83-4; U. Nonn, Zur Verwaltungsorganisation in der nördlichen Galloromania, in D. Geuenich (ed.), Die Franken und die Alemannen bis zur „, Schlacht bei Zülpich“ (496/97). Ergänzungsbände zum Reallexikon der Germanischen Altertumskunde, 19, Berlin, 1998, p. 82.

121 E. Ewig, Die fränkische Reichsbildung, in T. Schieffer (ed.), Handbuch der europäischen Geschichte, 1, Europa im Wandel von der Antike zum Mittelalter, Stuttgart, 1976, pp. 254-5; E. Ewig, Die Rheinlande in fränkischer Zeit, in F. Petri, G. Droege (ed.), Rheinische Geschichte, 1, Altertum und Mittelalter, 2, Frühes Mittelalter, Düsseldorf, 1980, p. 13; cf. E. Ewig, Clovis I (Chlodovechus), in Lexicon des Mittelalters, 2, Munich, 1983, col. 1863; K. Schäferdiek, Remigius von Reims. Kirchenmann einer Umbruchszeit, in K. Schäferdiek, W.A. Löhr, H.C. Brennecke (ed.), Schwellenzeit. Beiträge zur Geschichte des Christentums in Spätantike und Frühmittelalter, Berlin, 1996, p. 311. 
project as it was to pre-war nationalisms, albeit for different reasons; administrative continuity looms large still, but so does what the letter may say as to religious accommodations. Prolonged examination is confined to what it means for relations between the king and the bishops who, one way or another, bent him to their will. B.S. Bachrach deploys the 'veiled threat' of EA 2 to illustrate the power of the episcopate, while Edward James deems it 'an astonishing letter to write to a pagan teenager, portraying him as if he was a Roman official and referring to his bishops', even as Patrick Geary contends that 'the young Frank was recognized by the GalloRoman leadership as the administrator of Belgica Secunda and that although a pagan, he was expected to serve the Christian Roman community'. ${ }^{122}$ Ian Wood, meanwhile, is struck by how Remigius could manage to attribute the military success of Clovis to divine judgement despite his king being a pagan. ${ }^{123}$ For Brygida Kürbis, the letter is straightforwardly the archetype of all pastoral missives to sovereigns spelling out their Christian responsibilities. ${ }^{124}$

122 B.S. Bachrach, Merovingian Military Organization, 481-751, Minneapolis, 1972, p. 7; E. James, The Origins of France: from Clovis to the Capetians, 500-1000, London, 1982, p. 29; P. Geary, Before France and Germany: the Creation and Transformation of the Merovingian World, Oxford, 1988, p. 82; cf. É. Demougeot, La formation de l'Europe et les invasions barbares, 2 vols., Paris, 1969-79, 2, pp. 685-8; J.N. Hillgarth, Christianity and Paganism, 350-750: the Conversion of Europe, rev. ed., Philadelphia, 1986, pp. 74, 76; R.W. Mathisen, Roman Aristocrats in Barbarian Gaul: Strategies for Survival in an Age of Transition, Austin, 1993, pp. 121, 125; M. Sot, Le baptême de Clovis et l'entrée des Francs en romanité, in Bulletin de l'Association Guillaume Budé, 1, 1996, pp. 66-7; J. Heuclin, Hommes de Dieu et fonctionnaires du roi en Gaule du Nord du V $V^{e}$ au IXe siècle, Villeneuve-d'Ascq, 1998, pp. 38-9; L. Pietri, La chrétienté gauloise de la division à l'unité retrouvée, in J.-M. Mayeur et al. (dir.), Histoire du Christianisme des origines à nos jours, 3, Paris, 1998, pp. 332, 342-4; B. Beaujard, Le culte des saints en Gaule. Les premiers temps. D'Hilaire de Poitiers à la fin du VI siècle, Paris, 2000, pp. 122-5; P. Geary, The Myth of Nations: the Medieval Origins of Europe, Princeton, 2002, pp. 116-7; G.I. Halfond, Vouillé, Orléans (511), and the Origins of the Frankish Conciliar Tradition, in R.W. Mathisen, D. Shanzer (ed.), The Battle of Vouillé, 507 CE. Where France Began, Berlin, 2012, pp. 161-2; S. Valente, Chlodoueci Aduentus: foi et politique en Gaule, M.A. Thesis, University of Ottawa, 2012, pp. 18-52, 102; B. Jussen, Chlodwig der Gallier. Zur Strukturgeschichte einer historischen Figur, in M. Meier, S. Patzold (ed.), Chlodwigs Welt: Organisation von Herrschaft um 500, Stuttgart, 2014, pp. 32-3.

123 I. Wood, Gregory of Tours and Clovis, in RBPH, 63, 2, 1985, pp. 259, 261-2, 264, 271; cf. I. Wood, The Merovingian Kingdoms, 450-751, London, 1994, pp. 40-41; D. Shanzer, Dating the Baptism of Clovis: the Bishop of Vienne vs the Bishop of Tours, in EME, 7, 1, 1998, p. 47; D. König, Bekehrungsmotiv. Untersuchungen zum Christianisierungsprozess im römischen Westreich und seinen romanischgermanischen Nachfolgern (4.-8. Jahrhundert), Husum, 2008, pp. 88, 472.

124 B. Kürbis, Studia nad Kodeksem Matyldy III. List księżnej Matyldy do Mieszka II, in Studia Źródłoznawcze, 30, 1987, pp. 140, 148; cf. V.A. Tyrell, Merovingian Letters and Letter Writers, Ph.D. Thesis, University of Toronto, 2012, pp. 132, 310 . 
This rewritten text can serve opposing ends. Gundlach avowed that it made Clovis a Christian before 486, but Wood has it illuminate the policies of a king not baptized until 508 . P.S. Barnwell falls in line here, highlighting the 'precise terminology Remigius employed' to portray 'both Clovis and his ancestors as administering a Roman province - Belgica II', while Yitzhak Hen dates the letter to when Clovis took power there, an offer of 'close alliance with the Gallo-Romans and their most significant institution, the Church'. ${ }^{125}$ Hauck and his brand of philology have triggered a habit of hearing fanfare (rumor magnus) accompany the solemn entry of King Clovis into Reims as provincial governor, in a Romanizing riposte to the former image of his military acclamation; this refashioned portrait of Clovis is neither positive nor negative in its tone, but conscious of the Roman 'institutional realities', however fragmented, which frame his authority. ${ }^{126}$ In the same line, Michel Rouche reduces Clovis to a third-rate imperial bureaucrat, handed a Christian programme on how to be the perfect rector provinciae, prioritizing the human problem and the need to eschew bribes; he pauses only to remark that Remigius acts as if the Empire had not fallen. ${ }^{127}$ This consensus is embedded too in the articles prefacing a fine re-examination of the burial of Childeric, where Karl Ferdinand Werner and Edward James deploy EA 2 to characterize the father of Clovis as a thoroughly Roman soldieradministrator of Belgica Secunda. ${ }^{128}$ Grave danger: when faulty interpretation of a text enters

125 P.S. Barnwell, Emperors, Prefects and Kings: the Roman West, 395-565, London, 1992, pp. 93-4; Y. Hen, Clovis, Gregory of Tours, and Pro-Merovingian Propaganda, in RBPH, 71, 2, 1993, p. 275; cf. W.M. Daly, Clovis: How Barbaric, How Pagan?, in Speculum, 69, 3, 1994, pp. 631-3.

126 O. Guillot, Les origines de la France (de la fin du $V^{e}$ siècle à la fin du $X^{e}$ ), in O. Guillot, Y. Sassier, Poivoirs et institutions dans la France médiévale, 2 vols., Paris, 1994, 1, pp. 54-5; A. Chauvot, Images positives, images négatives des Barbares dans les sources latines à la fin du Ve siècle et au début du VIe siècle après J.-C., in M. Rouche (dir.), Clovis: histoire et mémoire, 2 vols., Paris, 1997, 1, Le baptême de Clovis, l'événement, p. 12; O. Guillot, Clovis "Auguste», vecteur des conceptions romano-chrétiennes, in Rouche (dir.), Clovis, 1, pp. 708-9; cf. J. Barbey, Être roi. Le roi et son gouvernement en France de Clovis à Louis XVI, Paris, 1992, pp. 18-9; L. Theis, Clovis de l'histoire au mythe, Brussels, 1996, pp. 54-5, n. 16; B. Dumézil, Les racines chrétiennes de l'Europe. Conversion et liberté dans les royaumes barbares, $V^{e}$-VIII siècle, Paris, 2005, pp. 145, 152, 218.

127 M. Rouche, Clovis, Paris, 1996, pp. 202-4, 387-92.

128 K.F. Werner, De Childéric à Clovis: antécédents et conséquences de la bataille de Soissons, in Revue Archéologique de Picardie, 3-4, 1988, p. 4; E. James, Childéric, Syagrius et la disparition du royaume de Soissons, in Revue Archéologique de Picardie, 3-4, 1988, p. 9; cf. K.F. Werner, Les origines (avant l'an mil), in J. Favier (dir.), Histoire de France, 1, Paris, 1984, pp. 286-7, 297-9; K.F. Werner, La 'conquête franque' de la Gaule: itinéraires historiographiques d'une erreur, in BECh, 154, 1, 1996, pp. 24-5; A. Dierkens, P. 
archaeological discussion with its faults concealed, it can end up furnishing a false framework for understanding finds later handled as if they were independent evidence.

Even the most radical treatments of the letter leave its emendation unquestioned. Guy Halsall queries many of the accepted facts about Gaul in the late $5^{\text {th }}$ century, pointing out how little we really know of the chronology, our reliance on Gregory of Tours, and his unreliability. He suggests that the Merovingians originated in a Roman army detachment which assumed a Frankish identity, and repeats what Remigius purportedly wrote: 'Clovis' parentes had ruled Belgica Secunda' ${ }^{129}$ Halsall reads early Frankish history such that he need not argue whether $E A 2$ dates from before or after the war with Syagrius, yet the possibility that it might not be from the 480s at all never enters his calculus. Penny MacGeorge, in her own reassessment of the kingdom of Soissons, summarizes the situation of the letter as either 481, on the accession of Clovis, or soon after 486, once he had consolidated his authority over Belgica Secunda, the only question its precise meaning for the administrative continuity of northern Gaul. ${ }^{130}$ Bruno Dumézil even states that Clovis received this 'missive of felicitations' on mounting the throne in 481/2, its counsel on ruling for the common good - in the Christian tradition of Ambrose, Augustine, and Eustache Deschamps - 'all the more piquant' since he was a pagan. ${ }^{131}$ Elena Malaspina therefore prints the emendation in the main text of her new edition of the collection, but dissents from Gundlach in dating the letter to 481/2 and rejecting its Christian content: 'it seems to me too general to constitute a reference to the Christianity of the addressee'. ${ }^{132}$

Emendation is now fact. The message of $E A 2$ is the 'marked propensity' of barbarian kingdoms, in the words of Andrew Gillett, 'to replicate the former administrative borders of

Périn, The $5^{\text {th }}$-Century Advance of the Franks in Belgica II: History and Archaeology, in E. Taayke et al. (ed.), Essays on the Early Franks, Groningen, 2003, pp. 165-93.

129 G. Halsall, Childeric's Grave, Clovis' Succession, and the Origins of the Merovingian Kingdom [2001], in G. Halsall (rev.), Cemeteries and Society in Merovingian Gaul, Leiden, 2010, pp. 170-73, 182-92.

130 P. MacGeorge, Late Roman Warlords, Oxford, 2002, pp. 125-30.

131 B. Dumézil, Écrire pour le bien de tous. Définition et éloge du bien commun dans les correspondances de l'époque mérovingienne, in Revue Française d'Histoire des Idées Politiques, 32, 2, 2010, pp. 232-3; cf. G. Gandino, Il mondo franco e l'ideologia dell'espansione, in Carlo Magno e le Alpi, Spoleto, 2007, pp. 27-8.

132 Malaspina, pp. 62-5, 114, n. 27. 
the Roman provincial administration'; the Fall of Rome will not take place. ${ }^{133}$ This conformity as to date and meaning is uniformly reflected in current sourcebooks and handbooks on the period. Stéphane Lebecq can speak for them all with these aperçus on 'the famous letter of Bishop Remigius to the young Clovis':

But Childeric was not only a military ally of Rome, he was an agent of Roman power. Although he was the king of a people and not the king of a territory, it is clear that he received an official delegation of territory authority in Northern Gaul; bishop Remigius of Rheims even congratulated the young king Clovis because, when he succeeded his father, he took over (I quote the letter) administrationem Belgicae Secundae, just like his parents (parentes tui) before him. We can be sure that Childeric controlled the civil administration of the Roman province of Reims. ${ }^{134}$

As with the early modern pursuit of the magister militum, this fictive administration of Belgica Secunda has been steadily projected into the past: from Clovis to his father Childeric via our letter, and from him to Count Paul, about whom we know only that his death led to Childeric seizing power; all three are now holders of a non-existent office in a province supposed to have been the nucleus of the Merovingian kingdom. ${ }^{135}$ For Matthias Becker the letter, a response to the 'loud rumour' of the defeat of Syagrius, shows Remigius naturally still thinking in the terms of Roman administration, and using its language to veil the usurpation of Belgica Secunda by Clovis. ${ }^{136}$ As the latest contribution to the field puts it, the letter is evidence that the provinces

133 A. Gillett, Envoys and Political Communication in the Late Antique West, 411-533, Cambridge, 2003, p. 28; cf. C. Wickham, The Fall of Rome Will Not Take Place, in B.H. Rosenwein, L.K. Little (ed.), Debating the Middle Ages: Issues and Readings, Oxford, 1998, pp. 45-57.

134 S. Lebecq, The Two Faces of King Childeric: History, Archaeology, Historiography, in T.F.X. Noble (ed.), From Roman Provinces to Medieval Kingdoms, London, 2006, p. 274; cf. R.W. Mathisen, People, Personal Expression, and Social Relations in Late Antiquity, 2 vols., Ann Arbor, 2003, 1, pp. 135-6, 2, pp. 108-9; R. Kaiser, Das römische Erbe und das Merowingerreich, $3^{\text {rd }}$ ed., Munich, 2004, p. 18; L. Pietri et al., Province ecclésiastique de Reims (Belgica Secunda). Topographie chrétienne des cités de la Gaule des origines au milieu du VIII ${ }^{e}$ siècle XIV, Paris, 2006, p. 17; A.C. Murray, From Roman to Merovingian Gaul: a Reader, Toronto, 2008, p. 260; L. Pietri, M. Heijmans, La Gaule Chrétienne (314-614) (Prosopographie chrétienne du Bas-Empire IV), 2 vols., Paris, 2013, 'Remigius 2', 2, p. 1601; J. Moorhead, The Roman Empire Divided, 400-700, $2^{\text {nd }}$ ed., New York, 2013, p. 80.

135 E. Ewig, Die Merowinger und das Frankenreich, $5^{\text {th }}$ ed., Stuttgart, 2006, pp. 16-7; E. Ewig, Die Franken und Rom (3.-5. Jahrhundert). Versuch einer Übersicht, in Rheinische Vierteljahrsblätter, 71, 2007, p. 36; cf. R. Kaiser, S. Scholz, Quellen zur Geschichte der Franken und der Merowinger, Vom 3. Jahrhundert bis 751, Stuttgart, 2012, pp. 100-101.

136 M. Becker, Chlodwig I.: Der Aufstieg der Merowinger und das Ende der antiken Welt, Munich, 2011, pp. 153-5. 
remained the framework of meaning for both the new and old elites, Frankish and Gallo-Roman alike. ${ }^{137}$ The letter may divide historians, but only between 481 and 486 - both still have their cadres. The earlier date fits rumor better, since it implies that the event was far from Reims, and Tournai (where Childeric was buried) is farther away than Soissons (where Syagrius was presumably defeated). Yet why, asks one scholar, take this advice seriously, when its 'recipient was a pagan teenager'? ${ }^{138}$ Because, another counters, the young king in Belgica Secunda was 'l'homme de Rome contre Syagrius', sympathetic to Christianity, collaborating with the Gallic Church, and legitimized by it in the most Roman terms. ${ }^{139}$

This far and no farther. Since Gundlach, Secundum Belgice has made the journey from history in square brackets to empirical truth. ${ }^{140}$ Such unanimity rests on slender support: a bold emendation offered without justification. The problem is not unique to this text, for editions in the Monumenta Germaniae Historica have a seldom appreciated tendency to interpret sources implicitly, by editorial presentation, rather than explicitly, by commentary. The result appears to be evidence when it is actually argument, lending specious textual authority to their historical judgements. These editions are provisional and polemical, and must be handled with care; often, as here, they create for themselves a splendid isolation, citing none of the rich scholarship with which they silently engaged. Once this conceit is dispelled, the Gundlach consensus is not so very different from the less outwardly disciplined theories of earlier scholars in the invigorating intellectual turbulence of previous centuries - a hypothesis; nothing more.

137 S. Dick, Childerich und Chlodwig: fränkische Herrschafts- und Gesellschaftsorganisation um 500, in Meier, Patzold (ed.), pp. 376-7.

138 J. Vanderspoel, From Empires to Kingdoms in the Late Antique West, in P. Rousseau (ed.), A Companion to Late Antiquity, Chichester, 2009, pp. 430-32.

139 M.-C. Isaïa, Remi de Reims. Mémoire d'un saint, histoire d'une Église, Paris, 2010, pp. 106-10, 777; cf. M.C. Isaïa, Rumor ad nos magnum pervenit. Information et circulation des nouvelles aux origines du royaume franc, in M. Billoré, M. Soria (dir.), La Rumeur au Moyen Âge. Du mépris à la manipulation (Ve-XVe siècle), Rennes, 2011, pp. 116-7; M. Becher, Chlodwig: zwischen Biographie und Quellenkritik, in Meier, Patzold (ed.), p. 58.

140 See E. Badian, History from 'Square Brackets', in ZPE, 79, 1989, pp. 59-70. 
Since $E A 2$ was copied in the $9^{\text {th }}$ century, no reader has been able to understand what it means as written. Everyone has fallen back on emendation, addition, or distortion to take some meaning out of it. Interpretation of the letter is marked by an excess of contradictory certainties: clearly dating to 481 , or 486 , plainly post-496, or else 507 , early or late; manifestly Christian, consigning the chronology of Gregory of Tours to the reject pile, or patently sent to a pagan king, rescuing his reliability; its opening proves that Clovis, and his forefathers Childeric and Merovech, were magistri militum, that Clovis had recently campaigned against an enemy, was readying to do so, or else had undertaken government of Belgica Secunda; it is patronizing, a bizarre missive to dispatch to a young pagan king, or the tender advice of a fatherly bishop; it shakes the iron fist of the Gallo-Roman episcopate at this ruler, or is a delicate despatch in the aftermath of the rout of Syagrius; it may not be addressed to Clovis at all (we have yet to hear that it was not written by Remigius). While modern comment aligns itself behind Gundlach in his edition and mostly in his date, these are not intrinsically better solutions to the problems of the text than those proposed by Sirmond or even $c^{i i}$. A cynic might expect that the outstanding questions of date and tone will only serve to attract future bold, indeed improbable conjectures, certain to be framed as the self-evident resolution to a seeming paradox.

The importance of $E A 2$ has never been in doubt and, amidst a scarcity of sources, to try to make use of it is only proper. But how? The letter is intractable: whereas $E A 1$ gives the historian quite a lot of material, and Gregory provides it with fair context, the next item in the collection drifts unmoored. Gundlach anchored the letter, offering a means to date it, a setting in which to get sense out of it, a text supporting his interpretation. Historians have accepted his work with gratitude, but at no point since he published has there been discussion as to whether his changes were correct - or plausible. A new orthodoxy, without argument or interrogation, maintained stubbornly in the face of the real difficulties of the text; it has become stale through lack of challenge, and bracing scepticism is badly needed. The protracted interpretive history 
of $E A 2$ has seen a perceptible flotation of the various positions on its meaning away from their moorings. The phenomenon dates back to when early modern scholars agreed with Sirmond without his textual basis, just as a dating first hazarded by Dubos now garners assent from those who would shy away from his individual project. The emended text of Gundlach, which he necessarily tied to a Christian Clovis, has likewise been adopted by both those who retain the date of his baptism in 496 or so and those who delay it until 508. The views set out above can be found in almost any combination, often compartmentalized into discrete historiographical strands, but there is no strong case for that amalgam of opinions now so entrenched - indeed there are considerable problems with it. Study of one of the few contemporary witnesses to the reign of Clovis is becalmed because we believe that its most insurmountable obstacles have long since been overcome. They have not.

\section{Commentary}

Our own approach is conservative: to intervene minimally and emend the received text as lightly as possible, explaining ourselves at every step. This can in fact be done, makes the text easier (not harder) to understand, and has never to date been attempted. We are also the first editors to take into account the fact that, like many late antique authors, Remigius writes prose with an accentual rhythm, one which yields certain predictable patterns at the end of clauses. ${ }^{141}$ The key point to note is that, in general, this confirms that the text as corrected by $c^{i i}$ is not corrupt: most clausulae have one of the three accepted rhythmical patterns.

\section{1-2 DOMINO INSIGNI ET MERITIS MAGNIFICO hlodoûeo RंEGI REMIGIUS EPISCOPUS}

141 For a brief introduction, see J.G.F. Powell, Prose-Rhythm, Latin, in S. Hornblower, A. Spawforth (ed.), The Oxford Classical Dictionary, $4^{\text {th }}$ ed., Oxford, 2012, pp. 1224-5. 
The headings of the $E A$ are original to the letters. ${ }^{142}$ Clovis is highlighted in lower case, and perhaps by the dotting of hlodoûeo and $\dot{R} E G I$. The spelling of his name in EA 1-2, lacking an initial $c$-, has no contemporary Gallic parallel, although many forms are attested; by the $9^{\text {th }}$ century, chl- tended to be simplified to hl-. ${ }^{143}$ DOMINUS is a standard honorific, but INSIGNI ET MERITIS MAGNIFICO is unique in this collection, indeed unique altogether. ${ }^{144}$ Remigius combines elements familiar from Roman titulature, but mentions no imperial honour as such, whereas he does explicitly call Clovis king. ${ }^{145}$

3 Rumor ad nos magnum peruenit .

The force of rumor is opposite to first-hand information: 'news', be it good or bad. ${ }^{146}$ Correspondents from Ruricius of Limoges to Peter the Venerable found rumor peruenit to be an apposite announcement to open their missives. ${ }^{147}$ The simplest solution for magnum is a gender error by author or scribe, thinking rumor to be neuter: it could be a case error for magnus, or else act adverbially, but the translation would be the same. ${ }^{148}$ Remigius has received 'important news', public knowledge not private to the bishop and king. Augustine, saluting Olympius on his recent (and bloody) elevation as chief minister of Honorius, wrote that fama

42 Barrett, Woudhuysen, pp. 43-4.

143 Avitus of Vienne, Ep 46, in R. Peiper (ed.), Alcimi Ecdicii Aviti Viennensis Episcopi Opera quae Supersunt. MGH AA VI.2, Berlin, 1883; Clovis, Ep ad episcopos; Orléans (511), Ep ad Regem, in C. de Clercq (ed.), Concilia Galliae, A. 511-A. 695. CCSL 148A, Turnhout, 1963; cf. Cassiodorus, Variae, II.41, III.3-4.

144 M.B. O’Brien, Titles of Address in Christian Latin Epistolography to 543 A.D., Ph.D. Thesis, Catholic University of America, Washington, 1930, p. 149.

145 See H. Wolfram, Intitulatio I. Lateinische Königs- und Fürstentitel bis zum Ende des 8. Jahrhunderts. MIÖG Ergänzungsbände, 21, 1967, pp. 44, 111-2.

146 Isaïa, Rumor, p. 112; M. Kempshall, Rhetoric and the Writing of History, Manchester, 2011, pp. 292-4. All other uses of rumor in Dümmler (dir.) bear this sense: Epp Arelatenses, 6, 15, 56; S. Bonifatii et Lulli Epp, 1, 6, 8, 10; Epp Aevi Merowingici, 5-6; Epp Wisigoticae, 18.

147 Ruricius of Limoges, Epistulae, in R. Demeulenaere, J. Mulders (ed.), Scriptores Minores Galliae. CCSL 64, Turnhout, 1985, II.22; Peter the Venerable, Epistulae, in G. Constable (ed.), The Letters of Peter the Venerable. Harvard Historical Studies 78, 2 vols., Cambridge, 1967, no. 64.

148 See C.T. Lewis, C. Short, A Latin Dictionary, Oxford, 1879, s.v. 'magnus', II.B.3; OLD, s.v. 'rumor'. 
had brought word; he was uncertain whether the rumour was true, but the point was to get in touch as soon as possible and urge him to a prudent (that is to say, anti-Donatist) use of his new power. ${ }^{149}$ Sidonius Apollinaris began one letter by saying, 'rumour is that the Goths have moved their camps onto Roman soil: we wretched inhabitants of Clermont are always the entrance for this attack', a vivid evocation of the spread of news and fear in wartime. ${ }^{150}$ Clovis himself, after invading the Visigothic kingdom, addressed his bishops by letter with the words Enuntiante fama ('Rumour reporting'). ${ }^{151}$ According to Gregory of Tours, the crowd at his trial in Berny-Rivière raised a rumor magnus questioning the charges levelled against him, whereas the Saxon $d u x$ Bertoald, counselling the campaigning Chlothar II to back away slowly, let it be known that his promised death would be a rumor magnus heard by all peoples. ${ }^{152}$ These words are dependent on context: they are flexible and have no inherent tone.

3-4 administrationem uos secundum bellicè suscepisse ;

The question is the meaning of secundum bellice. Both words are dotted over their final letters, which has encouraged emendation. In other cases of error $c^{i i}$ supplies a correction, but here has written $\dot{r}$ in the margin, for require, signalling that he simply does not understand. ${ }^{153}$ What $c^{i}$ wrote is clear enough, however, and there is good reason to accept it. Gundlach prints nonsense (Secundum Belgice has no meaning), and nonsense not present in the manuscript. At least Bethmann makes grammatical sense with his Secundae Belgicae, but the emendation as

149 Augustine, Epistulae, in A. Goldbacher (ed.), S. Aureli Augustini Hipponiensis Episcopi Epistulae, Pars II. Ep. XXXI-CXXIII. CSEL 34, Vienna, 1898, XCVI.1.

150 Sidonius Apollinaris, Epistulae, in A. Loyen (ed.), Sidoine Apollinaire, 3 vols., Paris, 1960-70, VII.1.1.

151 Clovis, Ep ad episcopos.

152 Gregory of Tours, DLH, V.49; Liber Historiae Francorum, in B. Krusch (ed.), Fredegarii et Aliorum Chronica. Vitae Sanctorum. MGH SSRM II, Hanover, 1888, c. 41.

153 BAV, Pal. lat. 869, fols. 19r, 27r (cf. 9v, 21v; 'r', 3r, 5r, 18v, 21v; long 'r', 15v, 17v, 24v; 'R', 7r, 9r, 11r, 29v); E.A. Lowe, The Oldest Omission Signs in Latin Manuscripts: their Origin and Significance, in E.A. Lowe, L. Bieler (ed.), Palaeographical Papers, 1907-1965, 2 vols., Oxford, 1972, 2, pp. 379-80; A. Cappelli, Lexicon Abbreviaturarum. Dizionario di Abbreviature latine ed italiane, $7^{\text {th }}$ ed., Milan, 2011, p. 495. 
it stands is gibberish - a vitiation of the text. Emending it to Secundum Belgice (for Secundae Belgicae) calls for both case and gender error, as well as a spelling mistake, which remains true even if one points to the form Bellica elsewhere. Regardless of one $6^{\text {th }}$-century manuscript of the Notitia Galliarum reporting this reading, the crucial objection is that $c^{i}$ himself does not confuse $l$ and $g$, as one may perceive from uulgus just four lines below bellice..$^{154}$ The formula administratio with a provincial name in the genitive is extremely rare, moreover, without any contemporary instances. ${ }^{155}$ The province, besides, was Belgica Secunda, all but never Secunda Belgica ( $\dot{r}$ for reverte, 'reverse', is also unattested). ${ }^{156}$ The sole $6^{\text {th }}$-century Gallic usage reflects this, and did not impel scribes to a riot of error: Gregory of Tours (for it is he) equates Belgica Secunda, the suburb of Reims, and its territory. ${ }^{157}$ In such confines, Remigius could scarcely pretend to have heard of a takeover by rumour, nor is it certain that the flashpoints of the early career of Clovis (Cambrai, Soissons, Tournai) were still thought to be in said region. Outside lists of provinces or offices, Belgica Secunda is non-existent; the one other $6^{\text {th }}$-century usage is by noted North African bishop Facundus of Hermiane, who ascribes it to Hilary of Poitiers two centuries earlier. ${ }^{158}$ Ewig was onto something when he cited EA 2 as the last gasp of this provincial name before three centuries of ensuing oblivion - he was only out by one. ${ }^{159}$ In sum, the 'emendation' is the wrong phrase in the wrong place.

These crucial words have sustained punishing critical bombardment, but what do they mean as written? For bellice, the logical implied complement of the feminine gender (bellicae)

154 BnF, lat. 12097, fol. 142r; Notitia Galliarum, in T. Mommsen (ed.), Chronica Minora I. MGH AA IX, Berlin, 1902, VI; $c f . E A$ 1, 'gloriosae', 'gloriam', 'neglecto'.

155 Firmicus Maternus, Matheseos Libri VIII, in W. Kroll, F. Skutsch (ed.), Julii Firmici Materni Matheseos Libri VIII. Bibliotheca Teubneriana, 2 vols., Leipzig, 1897-1913, II.29.10; Tacitus, Historiae, 2.58.1.

$156 N D$, in O. Seeck (ed.), ND, Berlin, 1876, Occ., I.46, I.74, III.20, V.140, XI.56, 57, XXII.8/27, XXXVIII.1, 6, XLII.39-42, 67; Laterculus Polemii Silvii, in Seeck (ed.), III.10; Verona List, in T.D. Barnes, The New Empire of Diocletian and Constantine, Cambridge, 1982, p. 203; $f$. Ammianus Marcellinus, XVII.3.6.

157 Gregory of Tours, Liber de Passione et Virtutibus Sancti Iuliani Martyris, in B. Krusch (ed.), Gregorii Episcopi Turonensis Miracula et Opera Minora. MGH SSRM I.2, 2 $2^{\text {nd }}$ ed., Hanover, 1969, c. 32.

158 Facundus of Hermiane, Pro Defensione Trium Capitulorum Libri XII (ad Iustinianum), in J.M. Clément, R. Vander Plaetse (ed.), Facundus Hermianensis. Opera Omnia. CCSL 90A, Turnhout, 1974, X.6.

159 E. Ewig, Kaiserliche und apostolische Tradition im mittelalterlichen Trier, in E. Ewig, H. Atsma (ed.), Spätantikes und Fränkisches Gallien. Gessamelte Schriften (1952-73), 2 vols., Munich, 1976-9, 2, p. 76. 
is rei, regularly omitted; ellipsis is a feature of epistolary brevitas, and res bellica is absolutely standard Classical and late Latin usage for 'conduct of war' or 'military matters', so we should take this word to be understood. ${ }^{160}$ The formula administrare rem bellicam is rare (compared with administrare bellum, well attested in contemporary literature), but it is used by Cicero and Sulpicius Severus in the same sense, 'to conduct a campaign, wage war', a bellicose counterpart to the far more common administrare rem publicam. ${ }^{161}$ By definition, as Charisius points out, the verb as a part of speech signifies administrationem rei (doing stuff). ${ }^{162}$ As for suscipio with administrationem, both cover a range of contexts - military, civil, managerial; the point is that their conjunction (not itself overly frequent) is a periphrasis for administrare, 'to administer, manage', without positive or negative force. ${ }^{163}$ One $6^{\text {th }}$-century follower of Cassiodorus, considering the qualifications required by St Paul for the episcopate, warned the prospective bishop to guard against the sin of pride and not to believe that he administrationem saeculi suscepisse, while Isidore of Seville recorded for the year 369 that Athanaric, becoming the first king of the Goths, administrationem suscepit. ${ }^{164}$ Clovis, in other words, is waging war.

What of secundum? Not the common preposition (no accusative object), it could be an adverb, 'for a second time', but this is exceedingly rare. More likely is the standard adjective,

160 TLL, s.v. 'bellicus'; e.g. Livy, Ab Urbe Condita, IV.41, V.26, IX.17, IX.38, XXII.25, XXXVI.10, XLIV.1; Lactantius, DI, in E. Heck, A. Wlosok (ed.), Divinarum Institutionum Libri Septem, 4 vols., Munich, 200511, I.22.4; Ambrose, De Officiis, in M. Testard (ed.), Sancti Ambrosii Mediolanensis de Officiis. CCSL 15, Turnhout, 2000, I.35; Pan Lat 2 (XII), 8.1 (see also 11 (III), 5.1; 12 (IX), 1.4); Eucherius of Lyon, Passio Acaunensium Martyrum, in B. Krusch (ed.), Passiones Vitaeque Sanctorum Aevi Merovingici et Antiquiorum Aliquot I. MGH SSRM III, Hanover, 1896, c. 3; Eugippius, Commemoratorium de Vita Sancti Severini, in P. Régerat (ed.-transl.), Vie de Saint Séverin. SC 374, Paris, 1991, c. 19; H. Halla-aho, Epistolary Latin, in J. Clackson (ed.), A Companion to the Latin Language, Chichester, 2011, pp. 430-34.

161 Cicero, De Divinatione, II.36 (76); Sulpicius Severus, Chronica, in G. Senneville-Grave (ed.), Chroniques. SC 441, Paris, 1999, I.50.4 (see also I.34.7); cf. II Samuel 11:7; Pan Lat 2 (XII), 32.1; Orosius, Historiarum Adversum Paganos Libri VII, in M.-P. Arnaud-Lindet (ed.-transl.), Histoires contre les païens, 2 vols., Paris, 1990-91, VII.15.7.

162 Charisius, Ars Grammatica, in K. Barwick, F. Kühnert (ed.), Flavii Sosipatri Charisii Artis Grammaticae Libri V, rev. ed., Leipzig, 1964, II.8.

163 OLD, s.v. 'suscipio', 8.a, 9.a; TLL, s.v. 'administratio', II, III.1.a-b; Ammianus Marcellinus, XXVI.7.4; CTh III.6.1 int., VI.22.8, 35.9; Dig. XXVI.7.39.8, XXVII.1.30.1, XLIV.7.5 pr., XLVII.2.54.3.

164 Disciple of Cassiodorus, Commentaria in Epistulas Sancti Pauli, ad Timotheum I, c. 3, in Migne (ed.), PL, 68, col. 665; Isidore of Seville, Historia Gothorum, in C. Rodríguez Alonso, Las historias de los Godos, Vándalos y Suevos de Isidoro de Sevilla. Estudio, edición crítica y traducción, León, 1975, c. 6. 
'another', which agrees with the sense of continuity at 1.4 . What this requires is emendation to secundam in order to qualify administrationem, a simple gender error perhaps made with the preposition in mind (in our English translation we render 'another' with 'war', by hypallage or transferred epithet, solely for the sake of style). ${ }^{165}$ The easiest interpretation of the marginal $\dot{r}$ is that it flags the need for this correction. One could also take secundam to mean 'successful', as proper to 'affairs or activities, especially military', which would account for the subsequent martial themes of the letter, but the bulk of it does not demand a great victory. ${ }^{166}$ Remigius has heard that his king has undertaken another war, or a successful one; this is a matter for historical judgement. Belgica Secunda vanishes, and with it the continuity of Roman provincial administration in Francia.

4-5 non est nouum - ut coeperis esse sicut parentes tui semper fuerunt .

Whatever has happened has happened before, and non est nouum ut is another formula with 'official' resonance, here in the Digest. ${ }^{167}$ And coeperis? This verb normally has inceptive force, but in late Latin, as in the Vulgate, it can act pleonastically with an infinitive to duplicate the perfect: 'you have been'. ${ }^{168}$ Clovis has done something - and coeperis cannot fix it at the start of his reign - which his parentes have already done. Remigius does not say pater, and this would be a jolly offhand way to mention Childeric if the letter dated to 481 when he had just

\footnotetext{
A. Blaise, Dictionnaire latin-français des auteurs chrétiens, Turnhout, 1962, s.v. 'secundum', 3.

$O L D$, s.v. 'secundus ${ }^{1}$, , 4 , b.

Dig. I.3.26, XIX.1.10, XXXVII.4.8.14, XLI.1.46, L.17.85.1.

168 J.N. Adams, Social Variation and the Latin Language, Cambridge, 2013, pp. 825-7, 836; P. Burton, Christian Latin, in Clackson (ed.), pp. 498-9; V. Väänänen, Introduction au Latin vulgaire, $3^{\text {rd }}$ ed., Paris, 1981, pp. 210 , 214; cf. A. Cain, Jerome and the Monastic Clergy, Leiden, 2013, pp. 263-4; H. Petersmann, Petrons urbane Prosa: Untersuchungen zu Sprache und Text (Syntax), Vienna, 1977, pp. 191-2; Julius Firmicus Maternus, C.A. Forbes (transl.), The Error of the Pagan Religions, New York, 1970, p. 191, n. 325; J.B. Hofmann, A. Szantyr, Lateinische Syntax und Stilistik, Munich, 1965, p. 796; B.H. Skahill, The Syntax of the Variae of Cassiodorus, Ph.D. Thesis, Catholic University of America, 1934, pp. 200-203; E. Löfstedt, Philologischer Kommentar zur Peregrinatio Aetheriae: Untersuchungen zur Geschichte der lateinischen Sprache, Uppsala, 1911, pp. 209-10.
} 
dropped dead. It is more probably an allusion to the ancestors of Clovis: EA 34 glosses parentes nostri ('our kin') as Francorum reges ('the kings of the Franks'). ${ }^{169}$ Remigius has heard that Clovis, once again, has done something warlike, in the manner of his predecessors. Such is the context - be it general (the belligerent Frankish kings) or particular (a specific conflict) - for the instructions which make up the balance of the letter.

$5 \quad$ Hoc inprimis agendum .

With est understood, this clause marks a shift from descriptive opening to imperative body. The hoc to come is a list of boilerplate sentiments with a long Classical pedigree in the standard rhetorical education, which Remigius could also have absorbed via the panegyrics of Sidonius Apollinaris, an obvious contemporary source. ${ }^{170}$ The stereotyped advice cannot prove that a campaign is in the planning, or ongoing, at the time of writing, for it suits peace as well as war; resist the temptation to argue for any date from the wholly conventional nature of the content or tone. When a later bishop contacted the newly enthroned Theudebert I, he adopted a polite and flowery voice in deference to their lack of acquaintance, whereas Remigius here is direct, which need not connote disrespect but familiarity; the first sentence aside, he does after all employ tu throughout (albeit uestro twice). ${ }^{171} \mathrm{He}$ is equally anodyne in $E A$ 1, written when he and Clovis were close: 'your soul duly composed, govern the kingdom the more shrewdly, taking sounder counsel in your zeal for serenity', superfluous for a king so experienced, by any chronology, at this point, and Clovis can scarcely have required a memo that 'you are the head

169 OLD, s.v. 'parens ${ }^{2}$ ', 2; cf. CTh X.5.1.

170 L.K. Born, The Perfect Prince According to the Latin Panegyrists, in American Journal of Philology, 55, 1, 1934, pp. 20-35; cf. D.A. Russell, N.G. Wilson (ed.-transl.), Menander Rhetor: a Commentary, Oxford, 1981, II.1-2, 10, 12.

171 EA 10; cf. Malaspina, n. 295. 
of the peoples, and you sustain the government'. The quality of the admonitions could simply reflect the constraints of writing to a king - sound advice does not suffer for repetition.

5-6 ut domini iudicium a te // non uacillet .

In this final clause (expressed with ne in Classical Latin), non gave $c^{i}$ some trouble; he wrote $n o-$, which $c^{i i}$ changed to $n$-, a standard abbreviation. ${ }^{172}$ There is no dodging the Christian sentiment of the clause, and the conclusion that the addressee was Christian: the king must not alienate the Lord. All who date letter before conversion must explain this - Gundlach at least faced the consequences of his early dating squarely. Protesting that it is 'not as Christian as it could be' is no way out, unprovable deduction from hypothesized tone used to contradict the plain meaning of words. The letter presumes that Clovis was Christian, even if it does not then tell us what kind, Arian or Catholic, nor if or when he had been baptized. ${ }^{173}$

6-7 ubi tui meriti qui per industriam humilitatis tuae ad summum culminisque peruenit .

While $c^{i i}$ has made no comment, this clause must be corrupt: the genitive tui meriti does not depend on anything, the relative pronoun qui lacks a masculine antecedent, and the following text through to peruenit is not subordinated to any main clause. The root of the problem is qui, which deprives us of this last and interrupts the chiasmus of tui meriti and humilitatis tuae, obviously related in some way. The source of the confusion may have been the following per: the original perhaps read quippe ('that is to say, indeed'), rather than qui, in

172 Cappelli, p. 228; W.M. Lindsay, Notae Latinae. An Account of Abbreviation in Latin MSS. of the Early Minuscule Period (c. 700-850), Cambridge, 1915, pp. 143-5; D. Bains, A Supplement to Notae Latinae, Cambridge, 1936, p. 25.

173 cf. Wood, Gregory of Tours, pp. 266-7; I. Wood, Arians, Catholics, and Vouillé, in Mathisen, Shanzer (ed.), Battle, pp. 139-41. 
some form which has been misunderstood. Standard abbreviations of quippe include $q p$ and $q p p$, with or without an $-e$; standing before per, itself shortened to $p$, it is easy to imagine a scribe confronting a string of $p$ s and thinking the $-p$ or - $p p$ of quippe duplicated, particularly since the $q$ - could also be written $q^{i}$, identical to the typical abbreviation of $q u i .{ }^{174}$ This proposal makes per industriam humilitatis tuae an explanation of or gloss on what precedes quippe, and gives us back our main clause. When then of tui meriti? These words are the context for what has happened, and, as the subsequent gloss shows, explain how it happened (by means of 'your merit'). There are two basic options: to emend to tuo merito, though it is hard to see why such a mistake would have been made, or to suppose that some word like causa or gratia has been lost. Since both were commonly abbreviated, causa to as little as the letter $c$, it is easy to see how either might have dropped out. ${ }^{175}$ We therefore suggest the diagnostic conjecture of causa before tui meriti. The striking phrase industriam humilitatis tuae cements the Christianity of the letter, and is a coinage of its author; both Avitus of Vienne and Nicetius of Trier similarly dwell on humility in their letters concerning the baptism of Clovis. ${ }^{176}$

Next is ad summum culminisque, where -que is apparently redundant; however, the prose rhythm (cursus planus) confirms it is authentic to the text, suggesting that something has dropped out, the other half of some pair of genitives, between the two words. Comparison with roughly contemporary texts indicates that fastigium was a natural complement to culmen, and offers a plausible restoration. ${ }^{177}$ We propose to read ad summum <fastigii > culminisque: 'to the height of the peak and the summit'. Finally, peruenit, which is typically read in error of person for pervenisti, or perueneris in the subjunctive with ubi. Yet ad summum <fastigii >

174 Cappelli, p. 312; Lindsay, pp. 251-2; Bains, p. 39.

175 Lindsay, pp. 92-6, 421-2.

176 Avitus of Vienne, Ep 46; EA 8; cf. G. Reverdy, Note sur l'interprétation d'un passage d'Avitus, in Le Moyen Âge, 26, 1913, p. 277, n. 2; von den Steinen, p. 483, n. 21.

177 e.g. Eusebius Gallicanus, De Revelatione Corporis Beati Stephani, in F. Glorie (ed.), Collectio Homiliarum, 3 vols., Turnhout, 1970-71, 3; Eusebius of Vercelli, De Trinitate Libelli Septem, in V. Bulhart (ed.), Eusebius Vercellensis Episcopi quae Supersunt, Turnhout, 1957, V.27. 
culminisque peruenit is not only a correct cursus planus, but also parallels a line of Ausonius, ad summum columen peruenit ('he has reached the highest peak'). The most recent subject of a main verb (at 11. 5-6) is domini iudicium, and so Remigius may mean to say here that Clovis must take care that the judgement of God not waver from him when it has reached such a high pitch through the qualities of the king - his merit and his humility.

The precise significance of the summum <fastigii > culminisque to which divine judgement has attained is unclear: perhaps just the peak of success, but the language is rich with official and honorary significance. Ausonius pairs summum columen with honorum for the praetorian prefecture; not the literal meaning here ( $c f .476 \mathrm{AD})$, but if a precise dignity it is clearly great. ${ }^{178}$ Gregory of Tours relates that the emperor Anastasius granted Clovis honours too: after defeating the Visigoths he was made consul or patricius. ${ }^{179}$ But this was an honorary dignity, 'a name, a shadow, an empty pageant', which added nothing to 'the actual, or legal authority of Clovis'; the 'antique title' suffused him in a Roman glow, tacitly recognising 'the usurpation of Gaul'. ${ }^{180}$ The bishops gathered at Clermont in 535 called the throne occupied by Theudebert I the culmen, and so in our letter a more elevated kingship than that of some Salian Franks circa 481 must be meant. ${ }^{181}$ The summum should be the preeminent kingship: Venantius Fortunatus labels Chlothar I, next king after Clovis to be sole ruler of Gaul, sublimi vertice rector ('ruler on the highest peak'). ${ }^{182}$ The conquest of Soissons in 486 just will not cut it. The populorum caput ('head of the peoples') in EA 1, here Clovis is a, or the, senior king. ${ }^{183}$

178 Ausonius, Epicedion in patrem, in R.P.H. Green (ed.), Decimi Magni Ausonii Opera, Oxford, 1999, 11. 41-2; cf. Symmachus, Ep IV.68, in O. Seeck (ed.), Q. Aurelii Symmachi quae Supersunt. MGH AA VI.1, Berlin, 1883; Ausonius, Lectori salutem, in Green (ed.), 11. 35-6; TLL, s.v. 'culmen', II.b.1-2.

179 Gregory of Tours, DLH, II.38 (with its 'Capitulatio'); cf. R.W. Mathisen, Clovis, Anastasius, and Political Status in 508 C.E.: the Frankish Aftermath of the Battle of Vouillé, in Mathisen, Shanzer (ed.), Battle, pp. 79110.

180 Gibbon, 2, p. 470.

181 Clermont (535), in de Clercq (ed.).

182 Venantius Fortunatus, Carmina, in M. Reydellet (ed.), Poèmes, 3 vols., Paris, 1994-2004, VI.2, 1. 49 (see also V.3, 1. 16).

183 cf. H.H. Anton, Troia-Herkunft, origo gentis und frühe Verfaßtheit der Franken in der gallisch-fränkischen Tradition des 5. bis 8. Jahrhunderts, in $M I O ̈ G, 108,1-4,2000$, p. 28, n. 83. 
Remigius represented this in the most Roman terms, perhaps drawing from an epistolary poem meditating on family attainment to link back subtly to Clovis equalling his kin.

7-8 quia quod $\cdot$ uulgus dicitur · actus hominis probatur ;

This is a problematic passage: the adage as written does not conform to the norms of accentual prose rhythm, yielding a trispondaicus, and since authors strove to avoid such, the text seems to be corrupt, something which the opaque sense tells the reader anyway. The origin of the saying is not certain, however, and so it cannot simply be restored. We leave the text in daggers, but the simplest solution is to read actus homines probant, for a planus (a clausula ending favoured by Remigius): this supposes that an abbreviation stroke above probat has been misread to stand for a passive, perhaps because of the ambiguous number of actus, and accepts a phonetic equivalence of $e$ and $i$ in hominis. As for the source, the closest usage is by Minucius Felix: 'but the mind is free, and so the action of a man (actus hominis), not the status, is judged (iudicatur) ${ }^{184}$ This must be the general idea, though perhaps not a citation, seeing that the text survives in only one copy, transmitted as book eight of the $4^{\text {th }}$-century anti-pagan tract Adversus Nationes by Arnobius Afer, teacher of Lactantius. ${ }^{185}$ Remigius more likely drinks of a common Classical well, but the parallel does clarify that the sense of probatur is not 'proven' but 'tested, judged'. The outstanding problem is uulgus, evidently a case error for uulgo. ${ }^{186}$

8-10 consiliarios tibi adhibere debes qui famam // tuam possint ornare et beneficium tuum castum et honestum esse debet .'

184 Minucius Felix, Octavius, in B. Kytzler (ed.), M. Minuci Felicis Octavius, Leipzig, 1982, 36.1; for the idea in general, see also Proverbs 27:21.

185 See BnF, lat. 1661, fol. 162r.

186 cf. C. Du Fresne, sieur Du Cange, L. Favre (rev.), Glossarium mediae et infimae latinitatis, 10 vols., Niort, 1884-7, s.v. 'vulgus'. 
The possent of $c^{i}$ has been corrected to possint by $c^{i i}$ for sequence of tenses. These royal consiliarios are distinct from the sacerdotibus and could be laymen, even magnates. Academic effort aside, beneficium is not a technical usage: such a meaning would in no way fit the general admonitory content of the letter, and the word came only slowly, from the late $7^{\text {th }}$ century, to designate a legal grant of land or a form of landholding. ${ }^{187}$ Read Lactantius and learn: 'nothing must be done by the just man except what is beneficium'. ${ }^{188}$

10-11 et sacerdotibus tuis honorem debebis deferre '. et ad eorum consilia semper // recurrere

The honorem is a marginal addition of $c^{i i}$, and unnecessary: the verb deferre can govern the dative sacerdotibus. The imperative recurre has also been altered to the infinitive recurrere by $c^{i i}$, the object of debebis. These sacerdotibus provide consilia, recalling the consiliarios, but who are they? Although the term could cover bishops and priests, in his other letters Remigius uses presbyter for 'priest' while calling himself sacerdos in his poesy; the bishops at Orléans (511) are likewise sacerdotes. ${ }^{189}$ Clovis ruled a large area if he had several bishops, and their qualification as tuis indicates close relations highly improbable if he were a pagan.

12-13 quod si tibi bene cum illis conuenerit · prouincia tua melius potest constare ;

187 Orléans (511), cc. 5, 7; J. Gaudemet, B. Basdevant-Gaudemet (transl.), Les canons des conciles mérovingiens (VI ${ }^{e}$-VII ${ }^{e}$ siècles), 2 vols., Paris, 1989, 1, pp. 76-7; J.F. Niermeyer, C. van den Kieft, J.W.J. Burgers (rev.), Mediae Latinitatis Lexicon Minus, 2 vols., Leiden, 2002, s.v. 'beneficium', 10; O. Gradenwitz, Heidelberger Index zum Theodosianus, Berlin, 1925, s.v. 'beneficium'; cf. P. Fouracre, The Use of the Term beneficium in Frankish Sources: a Society Based on Favours?, in W. Davies, P. Fouracre (ed.), The Languages of Gift in the Early Middle Ages, Cambridge, 2010, pp. 62-8.

188 Lactantius, DI, V.20.5.

189 EA 1, 3-4; Hincmar of Reims, Vita Remigii Episcopi Remensis, in Krusch (ed.), Passiones I, c. 2; Orléans (511), pr.; Niermeyer, s.v. 'sacerdos', 1-3. 
This periphrastic condition speaks to the need for harmony with bishops, a sentiment emphatically shared by $c^{i i i}$, our $14^{\text {th }}$-century reader. Difficulty comes with prouincia, which has been taken to support the case for Belgica Secunda. Yet the word bears a rampant diversity of meanings, from the offices of the Republic to the administrative divisions of the Roman state to the subdivisions of the successor kingdoms, and as the Church borrowed its governmental armature from the Empire it retained prouincia for its own units. ${ }^{190}$ In looser usage, just as in English, the term covers a range of public, private, and personal things, without any necessary geographical or administrative force. ${ }^{191}$ By 'province', Sidonius Apollinaris sometimes means Gaul, or perhaps only the Burgundian kingdom, at other times episcopal sees, moving between meanings within a few lines; for each reference to a Lugdunensis Secunda, he makes another to something as abstractly 'provincial' as historiography. ${ }^{192}$ Avitus of Vienne can employ it for his own diocese, while Church councils in the generation after Clovis use it for a metropolitan jurisdiction. ${ }^{193}$ The ambiguity is underlined by Caesarius of Arles: writing to Pope Symmachus in 513, he designated both Gaul and its subdivisions as prouinciae, also reportedly using it for regions whence paupers came to him and whither he sent his sermons (unsolicited). ${ }^{194}$

Precisely what Remigius and indeed Clovis understood by prouincia is unknowable the word is fundamentally elastic. Remigius describes some region, with bishops, which Clovis controls, as small as a province or as large as Gaul. The word choice could be studiedly vague, to avoid the more concrete regnum because Clovis, conquering in southern Gaul, negotiating

190 TLL, s.v. 'provincia', I.A.1.a-b, I.A.2.a.a, esp. II.1, B.1.a, B.2.a-b; Pactus pro tenore pacis, in Boretius (ed.), c. 16; Cassiodorus, Variae, III.1, 3; cf. R.L. Benson, Provincia = Regnum, in G. Makdisi, D. Sourdel, J. Sourdel-Thomine (ed.), Prédication et propagande au Moyen Age. Islam, Byzance, Occident, Paris, 1983, pp. 41-69.

191 TLL, C.1.a. $\alpha-\beta$.

192 Sidonius Apollinaris, Epp I.7.4, II.13.6, IV.18.2, 22.6, V.7, VII.5.3, IX.6; Sidonius Apollinaris, Carmina, in in Loyen (ed.), II, 11. 224, 232, V, 11. 40-53.

193 Avitus of Vienne, Epp 34, 40; Épaone (517), letter of Bishop Viventiolus; Clermont (535), c. 2; Orléans (538), c. 1; Orléans (541), c. 37; all in de Clercq (ed.).

194 Ep Arelatensis 27; Vita Caesarii, in G. Morin, M.-J. Delage, M. Heijmans (ed.-transl.), Vie de Césaire d'Arles. SC 536, Paris, 2010, I.20, I.55; cf. Vita Genovefae, in Krusch (ed.), Passiones I, cc. 12, 17; Vita Patrum Iurensium, in F. Martine (ed.), Vie des pères du Jura. SC 142, Paris, 1968, I.4. 
with the emperor, held a constitutionally equivocal position. ${ }^{195}$ When Remigius wrote $E A 1$, he spoke of a regnum, but whenever he penned EA 2 he did not, for whatever reason. His words, when pushed, lose specificity, and in place of categorical references we find only language of Roman resonance reused to describe the world after Rome.

13-14 ciues tuos erige .' adflictos releua .' uiduas foue .' orfanos nutri .'

Here $c^{i i}$ has been busy, changing ciuos to ciues, adflictos to afflictos (seemingly), and nutre to nutri. The ciues are notable, but not out of place: Clovis has sacerdotes, a prouincia, and so too ciuitates with ciues - the lexical world, still, of Roman political institutions. ${ }^{196}$ The various categories of people are linked by tetracolon; the ciues are tuos, as are the afflicted, the widows, and the orphans, sensible perhaps for a king who had just overrun some region. Yet listen to the prophet Isaiah: 'Learn to do right, seek justice, defend the oppressed, take up the cause of the orphan, plead the case of the widow' ${ }^{197}$ The advice is conventional, typical of what bishops expected and instructed Christian rulers from Constantine onward to do. ${ }^{198}$ So, Lactantius: 'A work of justice no less important is that of guarding and defending children and widows who are destitute and in need of aid. This is a universal prescription of divine law' ${ }^{199}$ When Clovis himself wrote to his bishops, he accordingly made sure to express his concern for the welfare of widows and children, or at least those with connections to the Church. ${ }^{200}$

\footnotetext{
195 Avitus of Vienne, Ep 46.

196 Épaone (517), c. 35, Orléans (549), in de Clercq (ed.), c. 11; Vita Genovefae, cc. 12-3; Vita Caesarii, cc. 10 , $13,17$.

197 Isaiah 1:17; see also Psalm 68:3-6.

198 See Eusebius of Caesarea, F. Winkelmann (ed.), Über das Leben des Kaisers Konstantin, $2^{\text {nd }}$ ed., Berlin, 1991, I.43; A. Cameron, S.G. Hall (transl.), Life of Constantine, Oxford, 1999, p. 87.

199 Lactantius, DI, VI.12.21; cf. Venantius Fortunatus, Carmina, VII.4, 11. 25-32; Vita Desiderii Cadurcae Urbis Episcopi, in B. Krusch (ed.), Passiones Vitaeque Sanctorum Aevi Merovingici II. MGH SSRM IV, Hanover, 1902 , c. 37.

200 Clovis, Ep ad episcopos.
} 
14 si potius est qu.am èrudies

This is a challenging clause, which has struck many a reader, and not without reason, as corrupt. The first four words seem to present no problem, 'if it is better than', but then we run smack into erudies. The two problems here are that si potius est is an otherwise unattested formulation, and to continue the preceding sequence of imperatives calls for erudi ('educate, raise, bring up'). For si potius est, we therefore suggest the rare but attested si potis est, meaning 'if it is possible'. ${ }^{201}$ The scribe misread this as si potius est and went on to supply quam for a comparative construction. (Note also that the dot in qu.am is an imperfection of the parchment; it appears in sag.acius on the recto of this folio.) He was unable, however, to get any further, leaving erudies, which $c^{i i}$ later came to dot in his own puzzlement, writing require in the left margin. If we take erudi to be the correct reading, we are left with es, and it is a short step from here to suppose eos, a suspension mark perhaps having been omitted. We thus reconstruct this passage as si poti\{u\}s est \{quam\} erudi e $\langle o\rangle_{s}$ : 'if it is possible bring them up'.

14-15 ut omnes te ament et timeant .

Remigius rhetorically complements te ament and timeant. Presumably it is taken as read that kings are feared - which a military undertaking will have encouraged - and he counsels a supplementary course of action to make him loved as well. An early medieval squaring of the Machiavellian circle, this is a Christian riposte to the famous tragic line put in the mouth of

201 e.g. Prudentius, Contra Symmachum, in M.P. Cunningham (ed.), Aurelii Prudentii Clementis Carmina, Turnhout, 1966, I, Praefatio, 1. 84, Liber Peristephanon, in Cunningham (ed.), III, 1. 102; Boethius In Librum Aristotelis Peri Hermeneias Commentarii (editio secunda), in K. Meiser (ed.), Anicii Manlii Severini Boetii Commentarii in Librum Aristotelis Peri Hermēnias, Leipzig, 1880, VI.14; cf. Ausonius, De Herediolo, in Green (ed.), 1. 18. 
Caligula by Suetonius: oderint dum metuant ('let them hate me so long as they fear me'). ${ }^{202}$ Hilary of Arles in his Vita Honorati was of the considered view that love led to the fear of sin, and fear to the love of discipline, while Augustine often spoke of the two together, memorably typifying the difference between the Old and New Testaments as fear versus love. ${ }^{203}$ The collocation came naturally to any student of the Psalmist. ${ }^{204}$

15 Iustitia ex ore uestro procedat;

The advice is generic, omnipresent in the Bible, but the image striking. The assumption that the king was responsible for justice to his subjects merits attention, even if it cannot resolve the contentious debate as to whether Clovis issued any surviving legislation. ${ }^{205}$

15-17 nihil sit sperandum de pauperibus uel peregrinis .' ne magis dona aut aliquid accipere uelis ;

The pauperes written by $c^{i}$ has been corrected by $c^{i i}$ to pauperibus, and uellis to uelis, a rather awkward comparative subjunctive. In $6^{\text {th }}$-century Gaul, peregrinis meant 'foreigners, travellers', but with a distinctly Roman legal hinterland: 'If any judge wishes to associate to himself as a counsellor (consiliarium) either citizens of the province (prouinciae) which he

202 Suetonius, De Vita Caesarum. C. Caligula, 30.1; cf. Seneca, De Clementia, I.12.4, II.2.2; Ovid, Heroides, XII.55; Valente, pp. 157-8.

203 Hilary of Arles, Vita Honorati, in S. Cavallin (ed.), P.-A. Jacob (transl.), La vie d'Hilaire d'Arles. SC 404, Paris, 1995, c. 17; Augustine, Contra Adimantum, in J. Zycha (ed.), Sancti Aureli Augustini Opera. CSEL 25, Vienna, 1891, c. 17; cf. Augustine, Ennarationes in Psalmos, in E. Dekkers, J. Fraipont (ed.), Sancti Aurelii Augustini Enarrationes in Psalmos. CCSL 38-40, 3 vols., Turnhout, 1956, XXXIX.20, LXX.1.1, LXXIX.13; Augustine, Contra Faustum, in Zycha (ed.), XXI.14; Augustine, Sermones, 272B; Fredegar, in J.M. WallaceHadrill (ed-transl.), The Fourth Book of the Chronicle of Fredegar: with its Continuations, London, 1960, IV.61; Patrick, Confessio, in L. Bieler (ed.), Liber epistolarum sancti Patricii episcopi, 2 vols., Dublin, 1952, 1, pp. 65, 83; Jonas of Bobbio, Vita Columbani, in B. Krusch (ed.), Ionae Vitae Sanctorum Columbani, Vedastis, Iohannis. MGH Scriptores Rerum Germanicarum in Usum Scholarum 37, Hanover, 1905, II.4.

204 e.g. Psalm 103:11, 13, 17.

205 cf. Wood, Merovingian Kingdoms, pp. 208-13. 
rules or indeed foreigners (peregrinos) [...]'. ${ }^{206}$ Lactantius again reveals the boilerplate quality: '[The just man] is to accept no gift from a poor man, so that anything he himself gives will be good because it was free. He is to answer a curse with a blessing, but he should never curse, so that no evil word may proceed out of the mouth of one who reveres the good word' ${ }^{207}$

17-18 praetorium tuum omnibus pateatur $\cdot$ ut nullus exinde tristis abscedat ;

The praetorium could also be thought to support a specific force for administrationem and secundum bellice. The term first designated where the praetor discharged his function, and by extension the residence - permanent or temporary - of any civil or military official; in late Roman legislation it is ubiquitous, and Pontius Pilate occupies a praetorium in the Vulgate. ${ }^{208}$ At times it could be the home of a foreign monarch; normally a government building, it could even be a grand private house. ${ }^{209}$ While the word may be taken variously, here the reasonable options are the palace or the campaign headquarters of Clovis. This could indicate that the letter was written to a king in the field, or just as well align with its theme of justice: the one certainty remains the linguistic framework of Roman rule.

18-19 paternas quascumque opes possides · captiuos exinde liberabis $\cdot$ et a iugo seruitutis absolues ;

206 CTh I.34.1 (with IV.6.3, VI.37.1, VIII.1.9, IX.1.10, 16.5, XII.1.161, XIII.11.13, XIV.2.4, XVI.2.37, 5.36); cf. Vita Caesarii, I.10, II.23-4; Vita Patrum Iurensium, II.14; Orléans (541), c. 7; F. Cardot, L'espace et le pouvoir. Étude sur l'Austrasie mérovingienne, Paris, 1987, p. 69; R.W. Mathisen, Peregrini, Barbari, and Cives Romani: Concepts of Citizenship and the Legal Identity of Barbarians in the Later Roman Empire, in American Historical Review, 111, 4, 2006, pp. 1011-40.

207 Lactantius, DI, VI.18.10 (see also VI.12.25).

208 TLL, s.v. 'praetorius', I.A; Gradenwitz, s.v. 'praetorium' (esp. CTh XV.1.35); Matthew 27:27; Mark 15:16; John 18:28, 33, 19:9; cf. Sidonius Apollinaris, Epp I.5.10, IV.20, V.7.5; Gregory of Tours, Liber de Miraculis Beati Andreae Apostoli, in Krusch (ed.), Miracula, c. 18.

209 TLL, I.A.2.b (citing this bit of EA 2), II.A.1-2; cf. Ausonius, Mosella, in Green (ed.), 1. 286; Cassiodorus, Variae, VII.5, XI.8, XII.22, XIV.3. 
Like debebis (1.11), the future active indicative liberabis is unexpected, but the change from the subjunctive may be simple rhetorical variety; in order to agree, the absoluas of $c^{i}$ has been corrected by $c^{i i}$ to absolues. The sense of paternas quascumque opes, recalling Clovis as emulator of his parentes, must be ancestral rather than parental wealth: if Childeric had just checked out, it would be one cold bishop who leapt in with stipulations on blowing his cash. There is, however, a connection with the letter of Clovis to the bishops, in which the king shows conspicuous regard for captives, although he does not himself moot paying for their release. ${ }^{210}$ Funding redemption was a royal duty, and indeed Alaric II gave Caesarius of Arles moneys to this end. ${ }^{211}$ There were many captives in southern Gaul after the turmoil of 507-8, but not only then, so their presence here is merely suggestive. ${ }^{212}$

20-21 si quis in conspectu uestro uenerit · peregrinum se esse non sentiat ;

The choice of conspectu is characteristically ambiguous. In Roman law it has the sense of judicial purview, from which developed a specifically Christian connotation of the oversight of God (to whom Remigius may not here be comparing Clovis). ${ }^{213}$ The use of peregrinum is a pointer back to the peregrinis treated above.

21 cum iuuenibus ioca · cum senibus tracta .'

Remigius produces a final flourish here, but if his take on Le roi s'amuse has a specific origin, it is unknown. Later Merovingian writers approved of politicians who were iucundus or

210 Clovis, Ep ad episcopos.

211 Vita Caesarii, I.20.

212 Vita Caesarii, I.32, 38; cf. W.F. Klingshirn, Charity and Power: Caesarius of Arles and the Ransoming of Captives in sub-Roman Gaul, in JRS, 75, 1985, pp. 183-203.

213 CTh I.16.10, II.10.4, IV.7.1, 9.1, VI.35.8, 36.1, VII.20.2, 22.5, XII.17.1, XVI.5.7; Blaise, s.v. 'conspectus'. 
congenial, and Sidonius Apollinaris (in speaking of a close friend) described sharing both seria and ioca with him, a Classical collocation popular in Late Antiquity. ${ }^{214}$ Clovis need not, any more than is true of Sidonius, be a particular age to interact with the parties here. Despite the grave judgement of many a serious historian, it is no more necessary that he be young to banter with youths than aged to hold conversations with the elderly.

21-22 si uis regnare.' / nobilis iudicari ·

The iudicare written by $c^{i}$ has been corrected by $c^{i i}$ to iudicari. This is a double infinitive construction with a nominative adjective acting adverbially: 'if you wish to be judged to reign nobly'; awkward in English, natural in Latin. Some hand distinct from the early $9^{\text {th }}$-century $c^{i i}$ has unhelpfully added punctuation between regnare and nobilis (not an obvious abbreviation, say for $e t$ ). The use of regnare picks up rex in the heading and is clear in force, while throwing the choice of prouincia instead of regnum into starker relief. The obvious sense of nobilis is the late Roman one, nobilitas with its official as well as social and moral connotations. ${ }^{215}$ Read together with the rest of the legal and administrative terminology of $E A 2$, the word indicates that Remigius, through his behavioural guidance, aimed to fit not only Clovis the ruler but also Clovis the man into the familiar categories of the late Roman world.

\section{Edition}

We offer the following text of EA 2 to consolidate and summarize the points made in the commentary, and we consider its implications in the conclusion. We have italicized minor

214 Sidonius Apollinaris, Epistulae, IV.4.1 (see also e.g. Sallust, De bello Iugurthino, 96.2; Pan Lat 11 (III), 12.3 ; Ausonius, Parentalia, in Green (ed.), VII, 1. 11); $c f$. I. Wood, Iocundus in fabulis: the Value of Friendly Advice, in L. Jégou et al. (ed.), Splendor reginae: passions, genre et famille. Mélanges en l'honneur de Régine Le Jan, Turnhout, 2015, p. 332.

215 See T.D. Barnes, Who Were the Nobility of the Roman Empire?, in Phoenix, 28, 4, 1974, pp. 444-9. 
corrections to the manuscript text, put all our diagnostic conjectures between angled brackets $(<>)$, and marked deletions with braces $(\{\})$.

II. Domino insigni et meritis magnifico Chlodoveo regi, Remigius episcopus.

[1] Rumor ad nos magnus pervenit administrationem vos secund am rei bellicae suscepisse; non est novum ut coeperis esse sicut parentes tui semper fuerunt. Hoc inprimis agendum, ut Domini iudicium a te non vacillet, ubi <causa> tui meriti quippe per industriam humilitatis tuae ad summum $<$ fastigii $>$ culminisque pervenit; ${ }^{216}$ quia quod vulgo $\{\mathrm{s}\}$ dicitur $\dagger$ actus hominis probatur $\dagger^{217}$

[2] Consiliarios tibi adhibere debes qui famam tuam possint ornare, et beneficium tuum castum et honestum esse debet. Et sacerdotibus tuis \{honorem\} debebis deferre et ad eorum consilia semper recurrere, quod si tibi bene cum illis convenerit provincia tua melius potest constare. Cives tuos erige, adflictos releva, viduas fove, orfanos nutri, si poti $\{u\}$ s est $\{$ quam $\}$ erudi eos, ut omnes te ament et timeant.

[3] Iustitia ex ore vestro procedat: nihil sit sperandum de pauperibus vel peregrinis, ne magis dona aut aliquid accipere velis. Praetorium tuum omnibus pateatur, ut nullus exinde tristis abscedat. Paternas quascumque opes possides, captivos exinde liberabis et a iugo servitutis absolves. Si quis in conspectu vestro venerit, peregrinum se esse non sentiat. Cum iuvenibus ioca, cum senibus tracta, si vis regnare nobilis iudicari.

\section{Conclusion}

So what is to be done with EA 2? There is no Secundum Belgice here, nor anything like it. The emendation on which so much scholarship rests is overdue for jettisoning, and without

216 ad summum culminis pervenit ] $c f$. Ausonius, Epicedion in patrem, 11. 41-2, 'maximus ad summum columen pervenit honorum, praefectus Gallis et Libyae et Latio'.

217 actus hominis probatur ] $c f$. Minucius Felix, Octavius, 36.1, 'mens tamen libera est et ideo actus hominis non dignitas iudicatur'. 
it no good reason remains to date the letter to 481 or 486 . There are sound grounds, indeed, to conclude that it cannot come from those years: it assumes that Clovis was Christian, the three other letters of Remigius date to the late 490s or later, no mention beyond parentes is made of Childeric (recently deceased) amidst talk of spending his money, and the king, an established ruler, has been brought to the summum through his Christian virtue. At the least it is incumbent on any who would retain an early date to deal with these facts, but none of them has been addressed or - since the early $20^{\text {th }}$ century - even acknowledged. There is no ready way to contextualize EA 2 unemended, but the plausible interpretations can be demarcated. The letter refers to war, but its prelude or its aftermath? Bishops wrote to kings before campaigns, even unprompted as rumor implies, and a letter of Avitus of Vienne shows that they felt it quite proper to offer advice at this moment. ${ }^{218}$ Yet Avitus gives military advice, keen to emphasize the (very Lactantian) connection between piety and victory, and while none of the counsel here is inappropriate to this context, it avoids most basic issues of war (inter alia, fighting, death). If the first lines mean instead that Clovis is recently victorious, could the letter be congratulatory? Given the link between sound Christian behaviour and military success, Remigius is more on topic than he may seem. But for which war? Procopius records that the Thuringians and Visigoths were troubled by the rising power of the Franks as early as 493, and in that period Clovis could well have suppressed one of his northern rivals, but such a contretemps would not have moved Remigius to write as he did. ${ }^{219}$ Mounting the summum meant more than victory over Ragnachar, king at Cambrai, or Syagrius of Soissons, whether or not either lay within his metropolitan province. The triumph must have been great: no wars of Clovis between circa 496 and 500 are documented, and his storied victories belong to the early $6^{\text {th }}$ century. The greatness could also be why its mention is so oblique, obvious to king

\footnotetext{
218 Avitus of Vienne, Ep 45.

219 Procopius, De Bellis, in J. Haury (ed.), G. Wirth (rev.), Procopii Caesariensis Opera Omnia, 4 vols., Leipzig, 1962-4, V.12.21.
} 
and bishop. Like the correspondence of Avitus and Sigismund on campaign, there may have been a series of letters, and only this most significant one was preserved for posterity (and study); the bishop of Vienne had also heard rumor of his king at war. ${ }^{220}$

The vocabulary of EA 2 assumes that, wherever Clovis abides, the environment is very Roman. Remigius had been educated in a Classical cultural idiom, and although his prouincia and praetorium may be thought to reflect the schoolroom rather than the locale of his addressee, Avitus could be quite explicit about the non-Roman character of northern Gaul and the Rhine, and he paid much attention to relations between Clovis and pagan barbarians. ${ }^{221}$ If Clovis were in the north, we should expect Remigius to deploy different terminology - to type his king as defender, rather than exemplar, of Roman virtue - and so his particular use of the language of Roman institutions may hint at the location of his king in victory, just as the bishop hearing the important news by rumour intimates that he is far from home (the peregrini likewise). All these indicators combined suggest that Clovis was somewhere in southern Gaul, sometime after 500, and recently victorious in battle. Conciliating citizens - and bishops - is always politic, and as he pacified his new domain, he would have resided in the praetorium of a general in the field, with captives whom he might ransom. Clovis rex, administering justice, was by then hardly new, and neither attribute provokes comment. Long ago Sirmond was attracted to the overlap of this text and the letter of Clovis himself after the war in Aquitaine; another point of contact is with his convocation of the Council of Orléans in 511 (such deference to his bishops). When evidence is scarce, it can be tempting to tie it all together, but the links are there.

Our letter may therefore be situated amidst one of the successful campaigns of Clovis in southern Gaul between 500 and his death in 511. This interpretation brings us close to the king remembered by the Vita Genovefae, composed perhaps a decade later: 'Clovis of glorious

\footnotetext{
220 Avitus of Vienne, Epp 45, 91-2.

221 Avitus of Vienne, Ep 46; $c f$. Sidonius Apollinaris, Ep IV.17, esp. 1-2.
} 
memory, king of wars' - rex bellorum recalling bellice? - 'and justly terrible', the Clovis too of Gregory of Tours, 'a great and outstanding fighter'. ${ }^{222}$ Such was certainly his afterlife at Reims, where Hincmar three centuries thence looked back on that 'singularly warlike battler' who had subdued Gaul. ${ }^{223}$ The vagueness of secundam ('another', but also 'victorious') reminds us that the history of Clovis at war is messier and less linear than Gregory of Tours would have it. ${ }^{224}$ We cannot confidently pick out a first campaign after 500 against the Burgundians and a second in 507 against the Visigoths, clear and chronologically discrete operations which the king, as if with a kind of late antique general staff, fought in successive seasons, to assert that it must be the latter. While 507 or after seems the most likely context, appearances may deceive, and so we resist picking any one date in the early $6^{\text {th }}$ century - such precision would only be illusory.

Exposition extended, conclusion concise. Epistula Austrasica 2 is one of few authentic documents from the foundation of the Frankish kingdom in the post-imperial West. In this lies its significance, yet it is in equal measure difficult, obscure, and frustrating. From the printing of the letter in 1613 to its edition by Gundlach in 1892, a diversity of competing interpretations reigned. The manuscript inaccessible, pseudo-transcriptions jostled quasi-translations; wildly divergent theories developed, predicated on the same imperfect text with a travelling circus of supplementary sources. Paradoxes abounded: arguments became detached from their bases as an orthodoxy coalesced, before fading without focussed defence. The ferment did not solve the letter, but the creativity, vigour, and often striking intellectual quality of the debate repay study. Progression from those arguments has come in part through forgetting rather than surpassing

222 Vita Genovefae, c. 56; cf. Vita Sulpicii Episcopi Biturigi, in Krusch (ed.), Passiones II, c. 6; Gregory of Tours, DLH, II.12.

223 Hincmar, Vita Remigii, c. 11, cf. Liber Historiae Francorum B, in Krusch (ed.), Fredegarii et Aliorum Chronica, c. 7; Wallace-Hadrill, pp. 163-4.

224 See G. Barrett, G. Woudhuysen, Clovis at War and Peace, forthcoming. 
them. The critical editions of the later $19^{\text {th }}$ century came caparisoned in what seemed science and certainty. ${ }^{225}$ Both were phantasms, bringing a hiatus to the creative debate of the preceding centuries. We have come to think too little of the earlier scholarship embodied in the Patrologia Latina, and too much of the modern achievement of the Monumenta Germaniae Historica. The scales are imbalanced; the work of each editor - Sirmond or Gundlach - needs to be considered with the same rigorous scepticism. For $E A 2$, a problematic emendation yielded a new letter, clearer and more useful than what had held its place, widely accepted and, as the period is dim but the creation bright, enduring in histories surprisingly diverse. Before clarity and honesty, it cannot stand: clarity about what the text can mean, honesty about what it can be made to prove. The letter does not date to 481 or 486 , it must postdate when Clovis became Christian, and it most plausibly dates to the period after 500, congratulating him on some recent victory.

We each create a Clovis of convenience: tool of absolutism, prop for aristocratic rights, Christian crusader, and now the proof that the Roman Empire never really fell, in an unending Late Antiquity of provinces, prelates, and the past. We are missing something. The point of the letter is intangible: the words resist every effort to force some fixed and certain meaning. This elusive generality is the message - not what is said, but how it is said. ${ }^{226}$ Rightly read, the letter is unchained from Roman administrative continuity, its importance no longer a demonstration that Belgica Secunda survived or that Clovis derived his legal authority from a grant of office. Instead it records a more subtle survival: of Roman political idiom after Rome. Our late antique world hints that this was what mattered, that rulers and ruled sought to keep familiar titles and insignia, to retain familiar patterns of thought, much more than to imitate imperial institutions exactly. Procopius muses on the Berbers of North Africa: 'it was a law among the Moors that no one should be a ruler over them, even if he was hostile to the Romans, until the emperor of

225 cf. Cheminade, pp. 360-61.

226 H.D. Williard, Letter-Writing and Literary Culture in Merovingian Gaul, in European Review of History, 21, 5, 2014, p. 695 . 
the Romans should give him the tokens of the office'. ${ }^{227}$ And not just the Moors, 'for the Franks never considered that their possession of Gaul was secure except when the emperor had put the seal of his approval upon their title'. ${ }^{228}$ A century later, when Jonas of Bobbio tried to sketch the course of Gallic history, he leapt in a single bound from the end of Empire to the age when the grandsons of Clovis enjoyed their own power and made war on Italy itself; between was but a hazy transition. ${ }^{229}$ What endures out here, beyond the Roman order, is a way of thinking about rule, of presenting and discussing it, rather than any given structure. Political culture was Roman in the $7^{\text {th }}$ and $6^{\text {th }}$ centuries, much as in the $5^{\text {th }}$ and $4^{\text {th }}$. What else could it be? Deposing Romulus Augustulus did not at a stroke create a new language of politics: people reached for the old paradigms. ${ }^{230}$ With care Remigius casts his Clovis as a Christian warrior king on campaign in southern Gaul, responsive to bishops, keen to establish himself as a successor to imperial rule in style more than substance - the very same Clovis who emerges from the only known communication to survive from the king's own hand.

St John's College, Oxford

All Souls College, Oxford

Procopius, De Bellis, III.25.5; H.B. Dewing (transl.), Procopius, 7 vols., Cambridge, 1914-40, 2, p. 201.

Procopius, De Bellis, VII.33.4; Dewing (transl.), 4, p. 439.

229 Jonas of Bobbio, Vita Iohannis, in Krusch (ed.), Ionae Vitae Sanctorum Columbani, c. 15; cf. Procopius, De Bellis, VII.33.2-6.

230 cf. S. Airlie, The Aristocracy, in R. McKitterick (ed.), The New Cambridge Medieval History, II. c. 700-c.900, Cambridge, 1995, p. 449; Y. Hen, Conversion and Masculinity in the Early Medieval West, in I. Katznelson, M. Rubin (ed.), Religious Conversion: History, Experience and Meaning, Farnham, 2014, pp. 156-7. 